Structural Integrity Program for the Calcined Solids Storage Facilities at the Idaho Nuclear Technology and Engineering Center

Jeffrey W. Bryant

Joseph A. Nenni

August 2008

CH2M-WG Idaho, LLC is the Idaho Cleanup Project contractor for the U.S. Department of Energy 


\title{
Structural Integrity Program for the Calcined Solids Storage Facilities at the Idaho Nuclear Technology and Engineering Center
}

\author{
Jeffrey W. Bryant \\ Joseph A. Nenni
}

August 2008

Idaho Cleanup Project

Idaho Falls, Idaho 83415

Prepared for the

U.S. Department of Energy

Assistant Secretary for Environmental Management

Under DOE Idaho Operations Office

Contract DE-AC07-05ID14516 


\begin{abstract}
This report documents the activities of the structural integrity program at the Idaho Nuclear Technology and Engineering Center relevant to the high-level waste Calcined Solids Storage Facilities and associated equipment, as required by DOE M 435.1-1, "Radioactive Waste Management Manual."

Based on the evaluation documented in this report, the Calcined Solids Storage Facilities are not leaking and are structurally sound for continued service. Recommendations are provided for continued monitoring of the Calcined Solids Storage Facilities.
\end{abstract}




\section{CONTENTS}

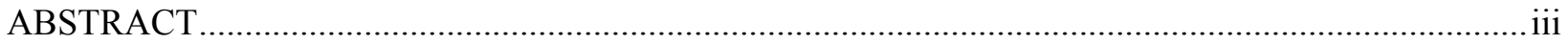

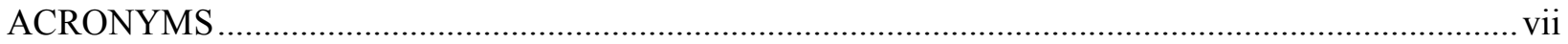

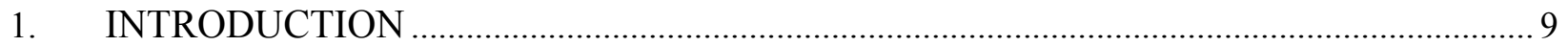

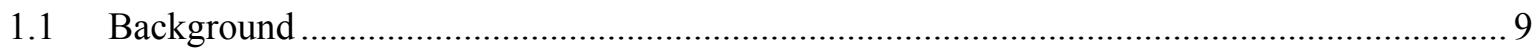

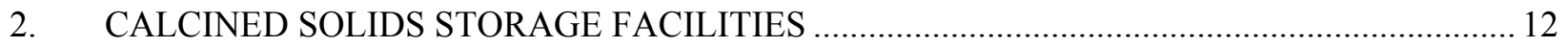

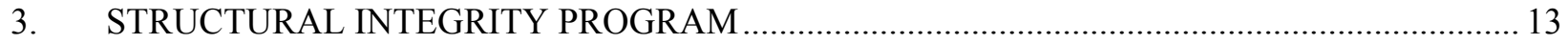

3.1 Calcined Solids Storage Facility Structural Integrity Program Description ........................ 13

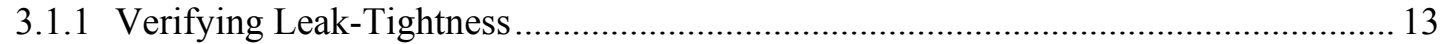

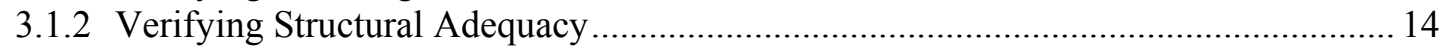

3.1.3 Identification of Degradation Mechanisms ................................................................. 15

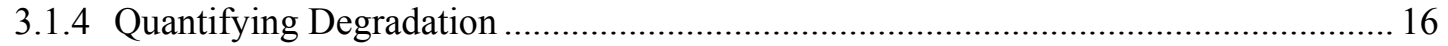

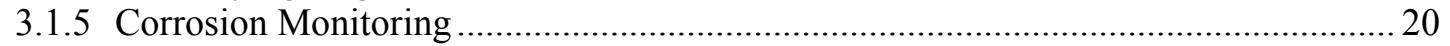

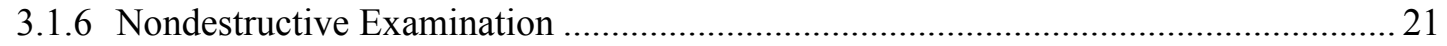

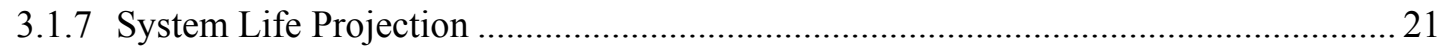

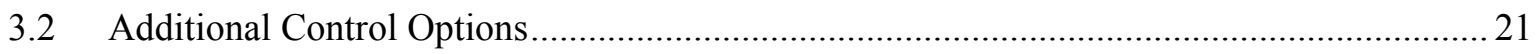

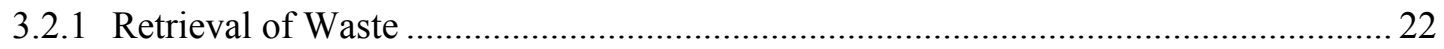

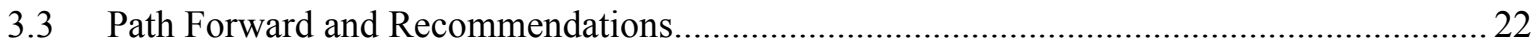

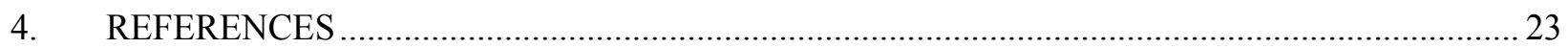

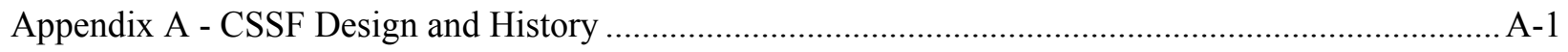

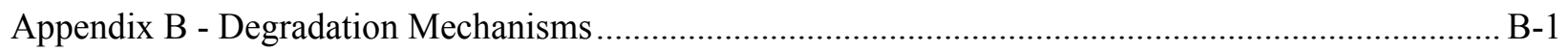

FIGURES

Figure 1. Process flow diagram at the Idaho Nuclear Technology and Engineering Center. 10 


\section{TABLES}

Table 1. Results of 1973 coupon retrieval from Calcined Solids Storage Facility II................................ 18

Table 2. Weight change (in grams) of corrosion coupons after 17 years of exposure to zirconia calcine.. 19

Table 3. Corrosion rates of alloys tested after 17 years of exposure ..................................................... 19

Table 4. Average corrosion rates of Type 304L welded stainless steel plate coupons in calcine.............. 20 


\section{ACRONYMS}

$\begin{array}{ll}\text { CAM } & \text { continuous air monitor } \\ \text { CSSF } & \text { Calcined Solid Storage Facilities } \\ \text { DOE } & \text { U.S. Department of Energy } \\ \text { HEPA } & \text { high-efficiency particulate air } \\ \text { HLW } & \text { high-level waste } \\ \text { ICPP } & \text { Idaho Chemical Processing Plant } \\ \text { INL } & \text { Idaho National Laboratory } \\ \text { INTEC } & \text { Idaho Nuclear Technology and Engineering Center } \\ \text { NWCF } & \text { New Waste Calcining Facility } \\ \text { PC } & \text { performance category } \\ \text { RCRA } & \text { Resource Conservation and Recovery Act } \\ \text { SBW } & \text { sodium-bearing waste } \\ \text { SNF } & \text { spent nuclear fuel } \\ \text { TFF } & \text { Tank Farm Facility } \\ \text { WCF } & \text { Waste Calcining Facility }\end{array}$




\section{Structural Integrity Program for the Calcined Solids Storage Facilities}

\section{INTRODUCTION}

This report provides a record of the Structural Integrity Program at the Idaho Nuclear Technology and Engineering Center (INTEC) at the Idaho National Laboratory (INL) relevant to the high-level waste Calcined Solids Storage Facilities (CSSFs) and associated equipment.

U.S. Department of Energy (DOE) Order 435.1, "Radioactive Waste Management,"1 requires management of all radioactive waste in accordance with the requirements in DOE M 435.1-1, "Radioactive Waste Management Manual." The manual states, "A structural integrity program shall be developed for each high-level waste storage tank site to verify the structural integrity and service life of each tank to meet operational requirements for storage capacity." The guide for the order, DOE G 435.11, "Implementation Guide,"3 which is to be reviewed when implementing DOE M 435.1-1 requirements, extends the applicability of the order to the CSSFs:

Although the analysis that prompted this requirement involved high-level waste storage systems that are likely to contain large quantities of liquid high-level waste for extended periods of time during which corrosion modes and rates could lead to loss of structural integrity, i.e., high-level waste underground storage tanks, high-level waste sites are encouraged to apply these requirements to all storage systems (e.g., process storage vessels, solid (calcined) high-level waste storage bins). ${ }^{3}$

The guide provides acceptable methods for meeting the requirements, but other methods may be used to ensure an adequate level of safety commensurate with the hazards associated with the work.

As required by DOE M 435.1-1, the guidance in DOE G 435.1-1 was reviewed during development of the INTEC structural integrity program. However, the facility design of the CSSFs and the nature of calcined solids, prevents closely following the additional guidance set forth in Guidelines for Development of Structural Integrity Programs for DOE High-Level Waste Storage Tanks by Brookhaven National Laboratory in Brookhaven in Upton, New York. ${ }^{4}$ Therefore, the INTEC structural integrity program will use other equivalent methods to address the structural integrity program requirements of DOE M 435.1-1.

Other process vessels are not used for storage of high-level waste (HLW) and are, therefore, not included under the structural integrity program.

\section{$1.1 \quad$ Background}

The information contained in this section was obtained from the Calcine Waste Storage at the Idaho Nuclear Technology and Engineering Center report unless otherwise indicated. ${ }^{6}$ Irradiated nuclear fuel has been stored and reprocessed at the INL since 1953 using facilities located at the INTEC (formerly the Idaho Chemical Processing Plant). A graphical representation of the INTEC mission is shown in Figure 1. Historically, spent nuclear fuel (SNF) was brought to INTEC from a variety of reactors throughout the world and was stored either underwater in pools or in dry storage facilities for an interim period. Some of the SNF was processed to recover uranium, lanthanum, neptunium, and krypton for DOE and its predecessor organizations, the Atomic Energy Commission and the Energy Research and Development Administration. 
The reprocessing activities at INTEC produced mixed liquid waste, which was stored in the TFF. Since 1963, most of the liquid waste has been solidified using a process called calcination. Calcination evaporates the water and other volatiles from the liquid waste and converts the remaining materials to dry granular solids. The calcined solids from this process are stored in specially designed stainless steel storage bins contained in concrete vaults. These structures are referred to as calcined solids storage facilities.

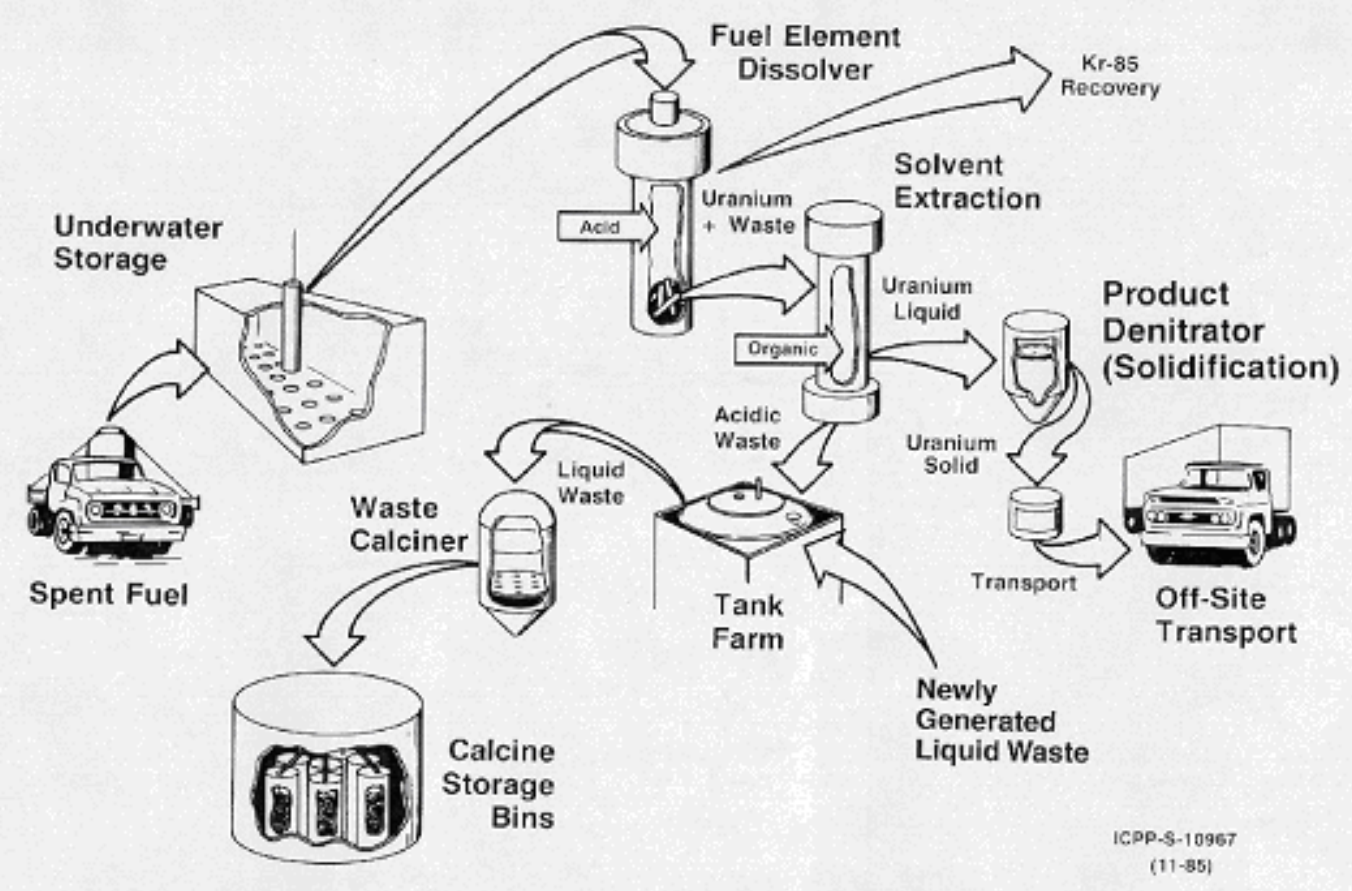

ICPP PROCESS FLOW

Figure 1. Process flow diagram at the Idaho Nuclear Technology and Engineering Center.

A variety of SNF types were processed at INTEC. Two types of liquid waste have been stored: HLW and sodium-bearing waste (SBW). High-level waste is the highly radioactive waste material resulting from the reprocessing of spent nuclear fuel, including liquid waste produced directly in reprocessing and any solids material derived from such liquid waste that contains fission products in sufficient concentrations; and other highly radioactive material that is determined, consistent with existing law, to require permanent isolation. ${ }^{2}$ The composition of the HLW was dependent on the type of spent nuclear fuel being processed, with aluminum and zirconium fuels producing the greatest volumes of waste. Previously, HLW was stored in the TFF; however, the last of the HLW was calcined in $1998{ }^{7}$

The liquid waste currently contained in the TFF is referred to as sodium-bearing waste (SBW) because of its high concentration of sodium ions, which is problematic to calcination (primarily resulting from bed agglomeration). The high sodium content resulted from processing and decontamination activities that made extensive use of sodium-based chemicals, such as sodium hydroxide and sodium carbonate.

From 1953 until INTEC calcination activities began, the high-level liquid waste from fuel dissolution and extraction reprocessing activities accumulated in the Tank Farm underground stainless 
steel tanks. From 1963 until 1981, the liquid waste was stored temporarily in the Tank Farm and was then transferred for calcining to the Waste Calcining Facility (CPP-633). From 1982 until 2000, Tank Farm waste was shipped to the New Waste Calcining Facility (NWCF) (CPP-659). In April 1992, DOE announced that SNF would no longer be reprocessed in Idaho and called for a shutdown of the facilities at INTEC. ${ }^{8}$ Since that time, no more HLW has been (or is planned to be) generated from SNF reprocessing, but SBW generation continues (and will continue at a reduced rate) as a result of SNF storage, waste management, off-gas cleanup, decontamination, and decommissioning of unused facilities. On February 20, 1998, the last of the liquid HLW that was stored in Tank WM-188 was calcined. ${ }^{7}$ On May 31, 2000, calcination activities in the NWCF were terminated. However, 37 years of calcination in the NWCF and previously in the WCF, have resulted in the production of approximately $4,400 \mathrm{~m}^{3}$ of calcine, which is stored in the CSSFs. ${ }^{9}$

A Settlement Agreement between the State of Idaho, DOE, and the U.S. Department of the Navy requires DOE to treat all high-level waste at the INL so that it is ready to be moved out of Idaho for disposal by a target date of $2035 .{ }^{10}$ Meeting that condition will first require retrieval of calcine from the CSSFs and packaging of the calcine into a form acceptable to criteria at Yucca Mountain, located $100 \mathrm{mi}$ northwest of Las Vegas, the designated repository for HLW. Under the Environmental Management Performance Management Plan for Accelerating Cleanup of the Idaho National Engineering and Environmental Laboratory, ${ }^{11}$ it is planned to retrieve, stabilize, package, and ship calcine to a repository by $2035 .{ }^{11}$. 


\section{CALCINED SOLIDS STORAGE FACILITIES}

From 1963 until 2000, the liquid radioactive waste stored at the Tank Farm was solidified using fluidized-bed calcination. Calcination is the process of converting liquid radioactive waste to dry granular solids. The liquid, primarily water and nitric acid, in the radioactive waste is evaporated and the dissolved metals and fission products are converted to salts and oxides. Each granule is about 0.3 to $0.7 \mathrm{~mm}$ in size. The solids are then transferred for interim storage to the CSSFs. Calcination typically reduces the volume of radioactive liquid waste 2 to 10 times. $^{12}$

During its most recent operations, the NWCF was operated at a higher temperature than previously, about $600^{\circ} \mathrm{C}$ instead of $500^{\circ} \mathrm{C}$. Operation at the higher temperature required smaller quantities of chemical additives, thereby allowing a quicker net reduction of the liquid waste stored at the Tank Farm.

During calcination when the liquid waste was injected into the heated calciner, it underwent thermal decomposition to form metallic salts, mainly oxides. The solids were transported to stainless steel cylindrically shaped bins. The bins are grouped in sets of three, four, or seven and are contained in concrete enclosures, called vaults. Each set of bins and its associated concrete enclosure is referred to as a bin set or CSSF. Currently, seven CSSFs are located at INTEC; however, only six contain calcine. The CSSFs were constructed over the years as additional storage was required, and the design has evolved in response to experience. Calcine storage temperature control was the prime design consideration and the basic designs have been modified to allow for the release of radioactive decay heat through natural convection. The basic design features of all the CSSFs include welded stainless steel construction, reinforced concrete enclosures, natural convective cooling, and filtered off-gas venting. Access/retrieval lines are installed in all of the CSSFs except CSSF I.

The principal reactions that occurred during calcination were evaporation and thermal decomposition of the liquid radioactive waste to form metallic salts, water vapor, and nitrogen oxides. The calcine produced during calcination of the solution from the TFF is referred to as alumina calcine, zirconia calcine, and sodium calcine, depending on the source of the solution. In addition, calcination of blends of the various liquid waste produced calcine blends of various compositions, the most common being a zirconium-sodium blend. Finally, calcine produced at higher temperatures during the last NWCF operating campaign is referred to as high-sodium calcine.

Table 1 provides the capacity and current contents of the CSSFs. ${ }^{6}$ 
Table 1. Volume of calcine in solids storage facilities.

\begin{tabular}{|c|c|c|c|c|}
\hline $\begin{array}{c}\text { Calcined } \\
\text { Solids Storage } \\
\text { Facility }\end{array}$ & $\begin{array}{c}\text { Total Storage } \\
\text { Capacity } \\
\mathrm{ft}^{3}\end{array}$ & $\begin{array}{c}\text { Usable Storage } \\
\text { Volume } \\
\mathrm{ft}^{3}\end{array}$ & $\begin{array}{c}\text { Calcine } \\
\text { Volume } \\
\mathrm{ft}^{3}\left(\mathrm{~m}^{3}\right)\end{array}$ & $\begin{array}{c}\text { Percent } \\
\text { Full }\end{array}$ \\
\hline I & 8,300 & 8,000 & $7,760 \quad(220)$ & 97 \\
\hline II & 31,600 & 30,000 & $30,000(850)$ & 100 \\
\hline III & 40,000 & 39,900 & $39,500(1120)$ & 99 \\
\hline IV & 17,700 & 17,100 & $17,200 \quad(486)$ & 100 \\
\hline V & 36,200 & 35,600 & $35,600(1010)$ & 100 \\
\hline VI & 55,200 & 53,200 & $25,200 \quad(713)$ & 47 \\
\hline
\end{tabular}

\section{STRUCTURAL INTEGRITY PROGRAM}

Structural Integrity Program requirements for leak-tight tanks in service are specified in DOE M 435.1-1, Chapter II, Section Q.2.a.

“A structural integrity program shall be developed for each high-level waste storage tank site to verify the structural integrity and service life of each tank to meet operational requirements for storage capacity. The program shall be capable of:

1. Verifying the current leak-tightness and structural strength of each tank in service;

2. Identifying corrosion, fatigue, and other critical degradation modes;

3. Adjusting the chemistry of tank wastes, calibrating cathodic protection systems, wherever employed, and implementing other necessary corrosion protection measures;

4. Providing credible projections as to when structural integrity of each tank can no longer be assured; and

5. Identifying the additional controls necessary to maintain an acceptable operating envelope."

\subsection{Calcined Solids Storage Facility Structural Integrity Program Description}

An effective program currently is in place for the CSSFs to address the structural integrity program requirements of DOE M 435.1-1. A summary of the structural integrity program is provided in this section. Additional details are provided, as necessary, in the appendices.

\subsubsection{Verifying Leak-Tightness}

Radiological monitoring of the CSSF vaults is provided through the use of continuous air monitors (CAMs). The CAMs monitor the vault atmosphere, and serve as a means of detecting airborne radioactivity levels higher than normal in the storage vaults if a release from the bins were to occur. If radioactive particulate matter is detected in the vault air, an alarm sounds in the NWCF control room. No 
such leaks have occurred. The vault and bins provide a double containment system for the radioactive calcine. Leakage from any of the bins will be contained in the vaults. ${ }^{13}$

Each CSSF vault is a reinforced concrete structure built on basalt bedrock. For CSSF II through VII, the below grade vertical portions of the concrete containment vault are coated with pitch to provide a watertight seal. Vault sump level readings are taken to detect in-leakage of groundwater into the CSSF vaults. $^{13}$

Underground concrete encased stainless steel pipes are used to transport the calcined waste to the storage facilities.

Because of the radiation levels within the CSSFs, direct visual inspections to detect deterioration are difficult to perform. However, the Partial Permit for Hazardous Waste Management Act Storage for the Calcined Solids Storage Facility at the INTEC on the $I N L^{13}$, requires periodic inspection of the various bin sets.

Video inspections of the vault interiors were performed in 2007 and documented in EDF-8527, Inspection of the INTEC Calcined Solids Storage Facility Vaults and Tank Systems ${ }^{14}$. The 2007 video inspection of CSSF I was compared with the video inspection performed in 1995. Little or no difference was noted between these two inspections. Additionally, video inspections of CSSF II through VI also showed that no deterioration/structural issues were detected with the bin sets, the exposed stainless steel piping, or the bin set vaults. Manned entry into CSSF VII also showed that the unit (vault, concrete walls and floors, integrity of the storage bins and sump) was in excellent condition. Based on these inspections and on-going monitoring of the CSSFs, the CSSFs are concluded to be leak-tight at this time. As a result of these inspections, the periodic inspection schedule has been set as follows:

\begin{tabular}{|c|c|c|}
\hline $\begin{array}{c}\text { Calcined } \\
\text { Solids Storage } \\
\text { Facility }\end{array}$ & Frequency & Inspection Years \\
\hline I & Biennially & $2007,2009,2011$, etc. \\
\hline II & Biennially & $2007,2009,2011$, etc. \\
\hline III & Biennially & $2007,2009,2011$, etc. \\
\hline IV & Every fifth year & $2007,2012,2017$, etc. \\
\hline V & Every fifth year & $2007,2012,2017$, etc. \\
\hline VI & Every fifth year & $2007,2012,2017$, etc. \\
\hline VII & Annually & $2007,2008,2009$, etc. \\
\hline
\end{tabular}

\subsubsection{Verifying Structural Adequacy}

The CSSF I vault was originally designed to the requirements of the Uniform Building Code version in effect in 1955 at the time of design and construction. Prior to 1970, the INL was in Seismic Zone $2,{ }^{15}$ which translates to a static lateral seismic design ground acceleration of $0.1 \mathrm{~g}$.

Two seismic evaluations were performed for CSSF I in the intervening years, ${ }^{16,17}$ but no seismic qualification calculations were completed. 
EQE Engineering performed the first evaluation for CSSF I in $1989 .{ }^{16}$ The scoping evaluation done in accordance with the commercial nuclear power plant criteria in effect at the time: Regulatory Guide 1.60 spectra with a $0.24-\mathrm{g}$ ground acceleration. ${ }^{16}$ The conclusion of the evaluation was that the vault may be overstressed, but should not collapse under earthquake loads.

Raytheon Corporation performed the second evaluation for CSSF I in $1995 .{ }^{17}$ This scoping evaluation was done in accordance with criteria for a Moderate Hazard earthquake zone: Regulatory Guide 1.60 spectra with 0.18 -g ground acceleration. ${ }^{17}$ The conclusion of the evaluation was that the south and east walls of the vault (the walls subjected to the berm surcharge) were overstressed, but should not collapse under earthquake loads.

In a separate Raytheon evaluation completed in $1995,{ }^{18}$ the south and east walls of the CSSF I vault were concluded to be overstressed under static soil pressure loads from the surcharge loads of adjacent berms. In addition, the evaluation included a prediction that if the vaults were significantly overstressed, cracks would develop along extensive portions of those walls. However, a video inspection done by the INL in 1995 established that the portions of the walls available for video inspection (essentially the top half of the walls) showed no structural cracking. ${ }^{19}$

In 2002, a structural evaluation ${ }^{20}$ of the CSSF I vault was performed in accordance with current DOE Performance Category (PC) 2 requirements as described in DOE-STD-1020-2002. ${ }^{21}$ Based on this evaluation, the CSSF I vault has been concluded to meet the requirements for a PC-2 structure. ${ }^{22}$ The Idaho Department of Environmental Quality has reviewed and concurs with the conclusions of this analysis. ${ }^{23}$ However, the CSSF I bins have not been evaluated to this criteria

The safety analysis for CSSF II and III provides seismic analyses that confirm the adequacy of the design to withstand the maximum credible earthquake at the INL. ${ }^{13,24}$

The safety analysis for CSSF IV indicated that the facility will withstand an earthquake with a bedrock acceleration of $0.33 \mathrm{~g}$ and a tornado with a maximum wind speed of 175 miles per hour, without releasing calcined material to the environment. ${ }^{13,25}$

The safety analysis for CSSF V noted that the bins, anchors, and all connecting components have been designed for resistance to the maximum bedrock acceleration of $0.33 \mathrm{~g}$ horizontal and $0.22 \mathrm{~g}$ vertical while operating at the design pressure and load. Also, CSSF V was designed with tornado protection features to prevent unacceptable radiological consequences if a design basis tornado strikes it. ${ }^{13,26}$

The design specifications for CSSF VI require that seismic design shall be performed by a dynamic analysis using the horizontal and vertical bedrock response spectrum curves specified in Regulatory Guide 1.60 scaled to $0.24 \mathrm{~g}$ horizontal and 0.16 g vertical. ${ }^{27}$

By combining information provided later concerning minimal corrosion in the bins with the seismic evaluations in this section, the CSSFs bins and vaults are concluded to be structurally adequate and the structural integrity of the CSSFs is confirmed.

\subsubsection{Identification of Degradation Mechanisms}

Several possible aging mechanisms were identified in the Brookhaven guidelines ${ }^{5}$, but none are considered to be significant for the CSSFs. The degradation mechanisms are presented Appendix B, with the more significant degradation mechanisms summarized below.

As the bins age, a variety of aging mechanisms may become operative that impact leak-tightness and the structural adequacy of the bin. The physical and chemical characteristics of the waste as well as 
the environment surrounding the bin structure can accelerate the aging process. The most significant degradation mechanisms for the calcine bins and transfer lines are erosion and corrosion. Elevated temperature and chemical attack are the most significant degradation mechanisms for the CSSF vaults. However, once the calcine is in the bins, no degradation mechanism will be significant in causing the bins to age excessively, provided that the calcine remains solid.

During filling of the bin sets, transfer line failures occurred due to erosion in areas where the direction of the calcine changed during transfer. The areas of the failures would not likely affect the bins because of the low velocity of the calcine as it entered the bins. These failure areas are no longer exposed to the calcine erosion. Erosion is therefore no longer a significant degradation mechanism for the CSSFs.

If water were to enter the bins, or if the calcine absorbed significant amounts of water from the atmosphere, then corrosion might become significant because calcine can become basic if dissolved in water. However, no scenario is credible for introduction of water into the bins. ${ }^{13}$ During the period of radiolytic decay, the bins are exposed to a hot, dry environment, but during cooler long-term storage conditions, humidity in the bins may cause a water film that contains chemical species leached from the calcine to form on the interior surface of the bins. The formation of this film depends on the humidity level in the bin or ingress of water. A thin water film would be needed to initiate corrosion degradation. However, because the bins are planned to be empty by $2035,{ }^{11}$ this degradation mechanism is not significant due to the calcine storage conditions.

When conventional concrete is exposed to elevated temperatures it begins to experience reactions involving the loss of absorbed and combined water from the cement paste and possible thermal incompatibilities between the cement paste and the aggregate. The result of this exposure is reduced compressive strength and stiffness of the concrete. ${ }^{4}$ However, design features of the CSSFs prevent the exposure of the concrete to excessive heat. Therefore, elevated temperature is not a significant degradation mechanism.

Some chemicals in solutions may cause degradation of concrete when the concrete is exposed to such solutions. The CSSF stored calcine or soils adjacent to the CSSFs do not have sufficient quantities of these chemicals to cause degradation of the concrete vaults with the introduction of water. In the unlikely event that a path were created for water to enter the bins and the dissolved calcine caused the bins to rupture, the released alkaline liquid would not likely cause degradation of the vault. Chemical attack from the outside of the vaults from soils and ground water also is minimized because the underground outside walls of all but CSSF I are protected with a coating of pitch. Visual inspection of the CSSF I vault in 1995 identified no visible evidence of structural defects, damage, or degradation to the storage vault walls. ${ }^{19}$ In addition, because the bins are planned to be empty by $2035,{ }^{11}$ this degradation mechanism is not significant.

\subsubsection{Quantifying Degradation}

A limited program to monitor bin construction material performance is being pursued at the INTEC. Corrosion coupons were installed in several of the bins during construction. Some of the coupons were removed and analyzed. In addition, laboratory testing was performed using simulated CSSF calcine to quantify degradation. These activities are discussed in the following sections.

\subsubsection{Analysis of Coupons Retrieved from Calcined Solids Storage Facility II}

During January 1966, 160 coupons were hung on 10 stainless steel cables in two empty bins in CSSF II. ${ }^{28}$ One of the bins was scheduled to contain zirconia calcine and the other alumina calcine. Each cable supported 16 coupons, four each of Type 405, 304, and 304L stainless steel and four of Type 1025 carbon steel. The coupons consisted of welded cylinders and plates fabricated from mill certified steels. 
The cylinders were rolled from a 1/8-in.-thick plate into welded tubes $15 \mathrm{~cm}(6 \mathrm{in}$.) long. The plate coupons were fabricated from $1 / 4$-in.-thick materials. For the plate coupons, two pieces of metal 3.8-cm (1$1 / 2$ in.) wide by $13 \mathrm{~cm}(5 \mathrm{in}$.) long were butt-welded to form a $7.6 \times 13-\mathrm{cm}(3 \times 5$-in.) coupon. All coupons were welded using the tungsten inert gas process with the appropriate electrode for the different alloys. Originally, the plan was that coupons would be retrieved during the fifth, $10^{\text {th }}, 20^{\text {th }}, 40^{\text {th }}$, and $80^{\text {th }}$ year of calcine storage.

During October 1973, one set of the coupons was retrieved from each of the two bins. As anticipated, one of the bins contained zirconia calcine and the other contained alumina calcine. The welded plate test coupons exposed to alumina calcine were in the bin for 6 years. The welded plate and cylinder test coupons exposed to the zirconia calcine were exposed for 2 years. The coupons were decontaminated in a boiling alkaline permanganate solution for 45 minutes followed by 15 minutes alternating nitric acid and water rinses. The effect of decontamination was subtracted from the observed corrosion. ${ }^{28}$

The results of the evaluation for each of the alloys in each bin are tabulated in Table 2 . The exposure temperatures of the coupons, as determined by the average of readings from a thermowell near the coupons for the years 1971 through 1973 , were $60^{\circ} \mathrm{C}\left(140^{\circ} \mathrm{F}\right)$ and $58^{\circ} \mathrm{C}\left(136^{\circ} \mathrm{F}\right)$ for the coupons suspended in the bin containing alumina calcine and zirconia calcine, respectively. ${ }^{28}$

The major conclusions drawn from the evaluation were that, based on the data, as compared to the corrosion allowances, the bins were suitable for long-term storage (up to 500 years as they were designed) of both alumina and zirconia calcine. Also, because of the low observed corrosion rates, the schedule for retrieval of the remaining coupons should be modified so that coupons are retrieved at the end of the $10^{\text {th }}$, $100^{\text {th }}, 250^{\text {th }}$, and $450^{\text {th }}$ years. ${ }^{28}$ 
Table 1. Results of 1973 coupon retrieval from Calcined Solids Storage Facility II. ${ }^{28}$

\begin{tabular}{|c|c|c|c|c|c|}
\hline \multirow[b]{2}{*}{ Alloy } & \multirow[b]{2}{*}{$\begin{array}{c}\text { Coupon } \\
\text { Type }\end{array}$} & \multicolumn{2}{|c|}{$\begin{array}{c}\text { Welded Plate Test Coupons Exposed } \\
\text { to Alumina Calcine } \\
\text { Exposure Time: } 6 \text { Years }\end{array}$} & \multicolumn{2}{|c|}{$\begin{array}{c}\text { Welded Plate and Cylinder Test } \\
\text { Coupons Exposed to Zirconia } \\
\text { Calcine } \\
\text { Exposure Time: } 2 \text { Years }\end{array}$} \\
\hline & & $\begin{array}{c}\text { Average } \\
\text { Corrosion Rate } \\
\text { (mils/year) }\end{array}$ & $\begin{array}{c}\text { Projected } \\
\text { Corrosion after } \\
500 \text { years (mils) }\end{array}$ & $\begin{array}{l}\text { Average } \\
\text { Corrosion Rate } \\
\text { (mils/year) }\end{array}$ & $\begin{array}{l}\text { Projected } \\
\text { Corrosion } \\
\text { after } 500 \text { years } \\
\text { (mils) }\end{array}$ \\
\hline \multirow{2}{*}{$\begin{array}{l}\text { Type } 1025 \\
\text { carbon steel }\end{array}$} & Plate & 0.024 & 12 & 0.079 & 40 \\
\hline & Cylinder & N/A & N/A & 0.056 & 30 \\
\hline \multirow{2}{*}{$\begin{array}{l}\text { Type } 405 \\
\text { stainless steel }\end{array}$} & Plate & 0.014 & 7 & 0.032 & 15 \\
\hline & Cylinder & N/A & N/A & 0.052 & 25 \\
\hline \multirow{2}{*}{$\begin{array}{l}\text { Type } 304 \\
\text { stainless steel }\end{array}$} & Plate & 0.003 & 2 & 0.008 & 5 \\
\hline & Cylinder & N/A & $\mathrm{N} / \mathrm{A}$ & 0.012 & 5 \\
\hline \multirow{2}{*}{$\begin{array}{l}\text { Type } 304 \mathrm{~L} \\
\text { stainless steel }\end{array}$} & Plate & 0.003 & 2 & 0.010 & 5 \\
\hline & Cylinder & N/A & N/A & 0.007 & 5 \\
\hline
\end{tabular}

\subsubsection{Laboratory-Scale Zirconia Calcine Corrosion Evaluations}

In October 1966, laboratory-scale tests were initiated to determine the long-term corrosion effect on materials exposed to zirconia calcine. ${ }^{29}$ During the tests, "as-welded" coupons fabricated from Types 405, 304, 304L, 316L, and 347 stainless steel, Type 1025 carbon steel, and aluminum 6061-T6 were exposed to nonradioactive zirconia calcine produced in the $30-\mathrm{cm}(1-\mathrm{ft})$ calciner pilot plant during Run $14 .^{30}$ The test vessel, containing the calcine and test coupons, was placed inside a tube furnace. The coupons were placed at varying points in the test vessel to determine whether temperature had an effect on corrosion rate. After each year of exposure, the coupons were decontaminated to remove any loose oxide film. During the decontamination process, the coupons were ultrasonically cleaned in distilled water for 15 minutes, rinsed in distilled water, dipped in isopropyl alcohol, dried in an oven at $100^{\circ} \mathrm{C}$ $\left(212^{\circ} \mathrm{F}\right)$ for 30 minutes, and air cooled.

During the first 2 years of testing, the temperature inside the vessel averaged $201^{\circ} \mathrm{C}\left(394^{\circ} \mathrm{F}\right)$ and ranged from $154^{\circ} \mathrm{C}\left(309^{\circ} \mathrm{F}\right)$ at the bottom to $206^{\circ} \mathrm{C}\left(403^{\circ} \mathrm{F}\right)$ at the top of the vessel. After the initial 2-year exposure period, all of the coupons being tested showed an increase in weight. The increase was presumed to result from the formation of an oxide film on the coupons. The coupons also became discolored, which can be indicative of oxide formation. ${ }^{29}$

During the following 15 years of testing, the temperature of the vessel was increased, resulting in an average temperature inside the vessel of $301^{\circ} \mathrm{C}\left(574^{\circ} \mathrm{F}\right)$ and a range of $204^{\circ} \mathrm{C}\left(399^{\circ} \mathrm{F}\right)$ at the bottom to $343^{\circ} \mathrm{C}\left(649^{\circ} \mathrm{F}\right)$ at the top of the vessel. During this period, most of the coupons stopped increasing and began to decrease in weight, at different times during the 15 -year period for the different alloys placed at the various locations. No correlation was apparent between when the decrease in weight began and the increase in temperature. Some of the aluminum 6061-T6 coupons were continuing to gain weight at the end of the test. ${ }^{29}$ 
After 17 year of exposure, most of the coupons showed an increase in weight over the start of the test. Only the Type 304, 304L, and 347 stainless steel coupons showed any decrease in weight. ${ }^{29}$ Table 3 shows the weight change of the coupons after 17 years of exposure.

Table 2. Weight change (in grams) of corrosion coupons after 17 years of exposure to zirconia calcine. ${ }^{29}$

\begin{tabular}{lcccccc}
\hline \multicolumn{1}{c}{ Alloy } & Bar 1 & Bar 2 & Bar 3 & Bar 4 & Bar 5 & Bar 6 \\
\hline Type 405 stainless steel & +0.0315 & +0.1159 & +0.1464 & +0.1245 & +0.0602 & +0.0066 \\
Type 304 stainless steel & +0.0041 & 0.0000 & -0.0082 & -0.0159 & -0.0840 & +0.0009 \\
Type 304L stainless steel & -0.0252 & -0.0157 & -0.0295 & -0.0098 & +0.0121 & +0.0021 \\
Type 316L stainless steel & +0.0019 & +0.0186 & +0.0188 & +0.0100 & +0.0026 & +0.0009 \\
Type 347 stainless steel & +0.0005 & +0.0060 & -0.0101 & +0.0047 & -0.0123 & +0.0027 \\
Type 1025 carbon steel & +0.0541 & +0.1894 & +0.2605 & +0.0796 & +0.0514 & +0.0047 \\
Type 6061-T6 aluminum & +0.0152 & +0.0300 & +0.0411 & +0.0316 & +0.0120 & +0.0012 \\
\hline
\end{tabular}

The results of the laboratory-scale testing were compared to the results from the CSSF II coupon evaluation performed from 1973 to 75 . To do this, the coupons from the testing were decontaminated similarly to those from CSSF II. This method of decontamination removes the oxide film from the surface of the coupon, whereas the less aggressive, distilled water ultrasonic cleaning does not remove the film. These results are listed in Table 4. When compared against the results shown in Table 2 for Type 304L coupons retrieved from CSSF II, the corrosion loss is almost identical, 4.48 mils (0.00448 in.) compared to 5 mils (0.005 in.). The data are important because CSSFs V, VI, and VII were fabricated from Type 304L stainless steel. ${ }^{29}$

The conclusions drawn from this study are that the corrosion rates for Types 304 and 304L stainless steel are very low and compare well to the rates calculated from the CSSF II coupons. Also, given the low rates, the interim before the next coupon retrieval should be extended from 10 years to 50 years. ${ }^{\text {Dirk }}$

Table 3. Corrosion rates of alloys tested after 17 years of exposure. ${ }^{29}$

\begin{tabular}{lcc}
\hline \multicolumn{1}{c}{ Alloy } & $\begin{array}{c}\text { Corrosion Rate } \\
\text { (mils/year) }\end{array}$ & $\begin{array}{c}\text { Estimated 500-year Corrosion Loss } \\
\text { (mils) }\end{array}$ \\
\hline Type 405 stainless steel & 0.000879 & 0.44 \\
Type 304 stainless steel & 0.00937 & 4.69 \\
Type 304L stainless steel & 0.00869 & 4.48 \\
Type 316L stainless steel & 0.00548 & 2.74 \\
Type 347 stainless steel & 0.0128 & 6.38 \\
Type 1025 carbon steel & 0.0167 & 8.36 \\
Type 6061-T6 aluminum & 0.0222 & 11.1 \\
\hline
\end{tabular}




\subsubsection{Laboratory-Scale High-Sodium Calcine Corrosion Evaluations}

In 2000, a study was performed to determine whether high-sodium calcine, because of its highly alkaline nature, would cause bin corrosion, and to quantify the rate of corrosion. ${ }^{31}$ Type $304 \mathrm{~L}$ welded stainless steel coupons were placed in containers of high-temperature calcine from several pilot plant tests. ${ }^{31}$ This calcine simulated calcines produced in the NWCF during 1999 and 2000. The coupons included plate coupons for immersion testing to determine general corrosion rates and U-bend coupons to determine whether the bins might be susceptible to stress cracking. The containers of calcine were placed in a Thermotron SE-1200L environmental chamber set at a temperature of $32^{\circ} \mathrm{C}\left(90^{\circ} \mathrm{F}\right)$ and $60 \%$ relative humidity for 2 months. At the end of 2 months, the coupons were removed from the chamber, cleaned, weighed, and visually examined under a microscope.

The result ${ }^{31}$ showed that the corrosion rates are very low. The maximum rate for any of the coupons was 0.0208 mils ( 0.00002 in.) per year, which corresponds to a penetration of 10 mils (0.01 in.) after 500 years, assuming general attack. The designed corrosion allowance for CSSF VI, where the calcine is stored, is 20 mils ( 0.02 in.). All of the results are tabulated in Table 5. The U-bend coupons indicated no corrosion or cracking. In addition, no localized corrosion was noted.

Table 4. Average corrosion rates of Type 304L welded stainless steel plate coupons in calcine. ${ }^{31}$

\begin{tabular}{lcc}
\hline Pilot Plant Test No. & $\begin{array}{c}\text { Average Corrosion Rate } \\
\text { (mils/year) }\end{array}$ & $\begin{array}{c}\text { Estimated 500-year Corrosion Loss } \\
\text { (mils) }\end{array}$ \\
\hline SBW-HT-10 & 0.0114 & 5.7 \\
SBW-HT-12 & 0.0094 & 4.7 \\
SBW-HT-15 & 0.0099 & 5.0 \\
\hline SBW-HT-16 & 0.0099 & 5.0 \\
\hline
\end{tabular}

The conclusions from these tests are that corrosion of the Type 304L stainless steel bins caused by high-sodium calcine occurs at an extremely low rate and that the bins are not susceptible to stress cracking. ${ }^{31}$

\subsubsection{Corrosion Monitoring}

All of the CSSFs except CSSF I contain corrosion coupons. Originally, it was planned to withdraw corrosion coupons from CSSF II on the $5^{\text {th }}, 10^{\text {th }}, 20^{\text {th }}, 40^{\text {th }}$, and $80^{\text {th }}$ year of solid storage. After the coupons were removed in October 1973 and examined following approximately 6 years of exposure, this schedule was revised to the $10^{\text {th }}, 100^{\text {th }}, 250^{\text {th }}$, and $450^{\text {th }}$ years based on evidence of very low levels of general corrosion. ${ }^{28}$ Subsequent laboratory tests resulted in the current plan for retrieval of coupons from the CSSFs after the $50^{\text {th }}, 100^{\text {th }}, 250^{\text {th }}$ and $450^{\text {th }}$ years of solids storage. ${ }^{29}$ Corrosion tests indicate that the CSSFs are fit for service for at least 500 years. ${ }^{28,29,31}$ Based on the testing performed to date and the characteristics of the calcined solids, the corrosion coupon examination schedule would be expected to provide adequate data to continue to verify the structural integrity of the CSSFs. The schedule for examination of the corrosion coupons in the CSSFs is provided below.

- $\quad$ CSSF I-No examination is planned for CSSF I because it does not contain corrosion coupons

- $\quad$ CSSF II-2066 for the second examination of CSSF II

- $\quad$ CSSF III-2022

- $\quad$ CSSF IV-2032 
- $\quad$ CSSF V-2033

- $\quad$ CSSF VI-2042

- $\quad$ CSSF VII-No examination is planned because it is empty.

Under the Environmental Management Performance Management Plan for Accelerating Cleanup of the Idaho National Laboratory it is planned to retrieve, stabilize, package, and ship calcine to a repository by 2035 , with construction of a calcine retrieval and packaging facility by $2020 .{ }^{11}$ This planned schedule closely matches the current corrosion monitoring schedule. Based on the retrieval schedule and periodic visual inspections required by the Partial Permit, no additional removal of corrosion coupons is planned prior to when the CSSFs are emptied.

\subsubsection{Nondestructive Examination}

No visual or ultrasonic examination monitoring is planned of the CSSF vessel internal or exterior surfaces or of the CSSF vault interior surfaces. Remote visual inspection of the upper half of CSSF I vault was performed in $1995,{ }^{19}$ after 22 years of service, and detected no visible degradation. Based on the testing performed to date, the characteristics of the calcined solids, and schedule for emptying the CSSFs, no nondestructive examination or any further inspections of the CSSFs are recommended until each of the CSSFs is emptied.

\subsubsection{System Life Projection}

The most unfavorable effect of degradation is leakage of the bin contents to the outside environment. If this were to occur, the bin could either be repaired or taken out of service, which is not an option for the CSSFs because of the highly radioactive nature of the calcine. Because of the highly radioactive nature of the CSSF calcines, the cost of repairing the bins would not likely be justifiable. Therefore, the preferred option is to, maintain the bins in a fit for service condition for their operating life. The effects of degradation can be quantified by estimating the service life of a bin. Service life is estimated by determining the ratio between the corrosion allowance of a bin and the corrosion rate that the bin has experienced, or is predicted to experience. Corrosion allowance is the amount of material that can be lost evenly from the surface of a bin before the bin becomes structurally inadequate to perform its intended function. The smallest reported total general corrosion allowance is 16 mils (0.016 in.) for CSSF IV. The highest average corrosion rate reported for any of the Type 304 corrosion coupons recovered from CSSF II was 0.012 mils (0.000012 in.) per year. Based on these data, the bounding service life of the bins in CSSF II - VI is about 1,300 years. However, this calculation is based on general corrosion from calcine; whereas localized corrosion attack can greatly shorten the life of a tank. In addition, no corrosion allowance was identified for CSSF I. ${ }^{24}$

\subsection{Additional Control Options}

Storage of calcined solids in the CSSFs is a passive operation with very little opportunity for the release of radionuclides. If a release of calcine to a CSSF vault were to occur, the CSSF vault is isolated from the atmosphere, with no active airflow, to prevent the spread of contamination.

The Settlement Agreement between the State of Idaho and DOE requires DOE to treat all HLW at the INL so that it is ready to be moved out of Idaho for disposal by a target date of $2035 .{ }^{10}$ Meeting that date will first require retrieval and packaging of the calcine into a form in compliance with criteria at the Yucca Mountain repository. 


\subsubsection{Retrieval of Waste}

No in-place transfer system exists to provide for retrieval of calcine in case of a leak. The policy of not having a spare bin has been in place since the inception of the CSSFs, and its basis has been documented since 1973. The policy was justified partly because the solids could not be removed from the vault spaces in the event of a bin failure. ${ }^{33}$ Although CSSF VII is empty, currently calcine cannot be transferred to it from other CSSFs in case of a leak. There are risers in the bins of all but CSSF I that can be used to retrieve calcine. Because of the very low likelihood of a leak, this design has been used for each subsequent CSSF. If necessary, holes will be cut into the top of the CSSF I bins to retrieve calcine. Over the years, several efforts have been made to investigate the feasibility of calcine retrieval, including a couple of calcine retrieval mock-ups. However, to date, no equipment has been developed to demonstrate all aspects of calcine retrieval. Development of retrieval equipment will be part of future activities aimed at emptying the bin sets.

An exemption to DOE M 435.1-1, "Radioactive Waste Management Manual,"2 requirements for contingency storage and transfer equipment has been approved ${ }^{34,35}$ to allow this configuration until a facility is constructed to support removal and treatment of calcine by 2035 in accordance with the Settlement Agreement. ${ }^{10}$

\subsection{Path Forward and Recommendations}

The conclusion of this structural integrity evaluation is that the CSSFs are not leaking and are structurally sound for continued service. Recommendations based on this evaluation include:

1. Continue monitoring of the CSSFs in accordance with the RCRA Partial Permit, PER-114. ${ }^{13}$

2. Develop a calcine retrieval system, and perform retrieval operations beginning in 2020 and continuing to 2035 . 


\section{REFERENCES}

1. DOE O 435.1, "Radioactive Waste Management,” U. S. Department of Energy, July 9, 1999.

2. DOE M 435.1-1, "Radioactive Waste Management Manual," U.S. Department of Energy, July 7, 1999.

3. DOE G 435.1-1, "Implementation Guide for use with DOE M 435.1-1," U. S. Department of Energy, July 9, 1999.

4. Bandyopadhyay, K., S. Bush, M. Kassir, B. Mather, P. Shewmon, M. Streicher, B. Thompson, D. van Rooyen, and J. Weeks, Guidelines for Development of Structural Integrity Programs for DOE High-Level Waste Storage Tanks, BNL-52527, Brookhaven National Laboratory, Upton, New York, January 1997.

5. Bryant, Jeffrey, Joseph A. Nenni, and Timothy S. Yoder, Structural Integrity Program for the 300,000-Gallon Radioactive Liquid Waste Storage Tanks at the Idaho Nuclear Technology and Engineering Center, INEEL/EXT-02-01549, Idaho National Engineering and Environmental Laboratory, Bechtel BWXT Idaho, LLC, Idaho Falls,Idaho, April 2003.

6. Staiger, M. D., and M. C. Swenson, Calcine Waste Storage at the Idaho Nuclear Technology and Engineering Center, INEEL/EXT-98-00455, Rev. 3, Idaho National Engineering and Environmental Laboratory, CH2M-WG Idaho, LLC, Idaho Falls, Idaho, June 2007.

7. Hovinga, J. E., Lockheed Martin Idaho Technologies Company, to J. L. Lyle, U.S. Department of Energy, Idaho Operations Office, "Completion of HLW Calcination," JEH-06-98, February 23, 1998.

8. U. S. Department of Energy, Memorandum from Assistant Secretary for Defense Programs to the Secretary of Energy, "ACTION: A Decision on Phaseout of Reprocessing at the Savannah River Site (SRS) and the Idaho National Engineering Laboratory (INEL) is Required," April 28, 1992.

9. U.S. Department of Energy, Environmental Management; U.S. Department of the Navy, Naval Nuclear Propulsion Program; and the State of Idaho, Settlement Agreement, October 17, 1995.

10. U. S. Department of Energy Idaho Operations Office, Environmental Management Performance Management Plan for Accelerating Cleanup of the Idaho National Engineering and Environmental Laboratory, DOE/ID-11006, Idaho Falls, Idaho, July 2002.

11. Palmer, W. B., P. A. Anderson, W. J. Dirk, M. D. Staiger, M. C. Swenson, and F. S. Ward, Status and Estimated Life of the 300,000-Gallon INTEC Tanks, INEEL/EXT-99-00743, Rev. 1, Idaho National Engineering and Environmental Laboratory, Lockheed Martin Idaho Technologies Company, Idaho Falls, Idaho, November 1999.

12. Safety Analysis Report for the Calcined Solids Storage Facilities, SAR-105.

13. Partial Permit for Hazardous Waste Management Act Storage for the Calcined Solids Storage Facility at the INTEC on the INL, PER-114.

14. Engineering Design File - Inspection of the INTEC Calcined Solids Storage Facility Vaults and Tank System, EDF-8527, November 26, 2007. 
15. Uldrich, E. D. and H. J. Dahlke, "The Evolution of Seismic Design Criteria at the Idaho Chemical Processing Plant,” WINCO 1069, 1989.

16. Hashimoto, P. S. and L. K. Downs, "Seismic Evaluation of Bin Set 1 at the Idaho Chemical Processing Plant," EQE Engineering, 1989.

17. Leavitt, B. and L. N. Amaria, "Idaho Chemical Processing Plant Bin Set 1 Calcine Recovery Project, Phase I and II Special Studies Report,” Raytheon Engineers \& Constructors, Inc., 1995.

18. Colasanti, R. and N. Amaria, "Idaho Chemical Processing Plant Bin Set 1 Vault Analysis for Static Loading, Final Report,” Raytheon Engineers \& Constructors, Inc., Project No. 9354.206, 1995.

19. Griffith, D. L., CSSF I Storage Vault Inspection Report, INEEL/EXT-97-01376, Lockheed Martin Idaho Technologies Company for U. S. Department of Energy, June 1998.

20. Plan for INTEC CSSF-1 Vault Seismic Qualification Analysis, PLN-705, September 9, 2002.

21. DOE-STD-1020-2002, "Natural Phenomena Hazards Design and Evaluation Criteria for Department of Energy Facilities," U.S. Department of Energy, January 2002.

22. Engineering Design File - PC-2 Qualification of INTEC CSSF-1 Vault, EDF-2439, September 4, 2002.

23. Monson, B. R., to J. T. Case, "INTEC Bin Set 1 Vault Seismic Qualification Analysis (INTECWP-02-068)," State of Idaho Department of Environmental Quality, November 21, 2002.

24. Lohse, G. E., Safety Analysis Report for the ICPP High-Level Solid Radioactive Waste Storage Facilities, ICP-1005, January 1972.

25. Schindler, R. E., Final Safety Analysis Report for the Fourth Calcined Solids Storage Facility, ENICO-1031, February 1980.

26. Exxon Nuclear Idaho Company, Inc. (ENICO), 1982, Final Safety Analysis Report for the Fifth Calcined Solids Storage Facility, ENICO-1068, January 1982.

27. EG\&G Idaho, Inc., Users Design Specifications for ICPP Sixth Calcined Solids Storage Facility Storage Bins, Subcontract No. 3289, November 1980.

28. Hoffman, T. L., Corrosion Monitoring of Storage Bins for Radioactive Calcines, ICP-1071, October 1975.

29. Dirk, W. J., Long Term Laboratory Corrosion Monitoring of Calcine Bin Set Materials Exposed to Zirconia Calcine, WINCO-1219, June 1994.

30. Newby, B. J. and B. H. O'Brien, Summary of Waste Calcination at the Idaho Nuclear Technology and Engineering Center, INEEL/EXT-2000-01206, October 2000.

31. Yoder, T. S., to J. A. Nenni, "Calcine Storage Bin Corrosion Test Results," TSY-01-01, January $15,2001$.

32. West, William, “Calcine Retrieval Uncertainties Meeting Record,” February 14, 2003.

33. Slansky, C. M., to D. E. Black, "Spare Bin Policy,” CMS-66-73, December 28, 1973. 
34. CCN 44394, Contract No. DE-AC-07-99ID13727 - Exemption Request for DOE M 435.1-1, "Radioactive Waste Management Manual," August 20, 2003.

35. CF\&AO-M\&O-04-116, Response to Request from BBWI to Exempt Requirements of DOE M 435.1-1, Radioactive Waste Management Manual, Contract No. DE-AC07-99ID13727, April 14, 2004. 


\section{Appendix A \\ CSSF Design and History}


A-2 


\section{Appendix A}

\section{CSSF Design and History}

\section{Calcine Composition}

The average composition of the calcine produced as a result of calcining the different liquid streams is contained in Table A- $1 .{ }^{1}$

A description of the design and the contents of each CSSF follows.

Table A-1. Average calcine compositions, excluding oxides, in weight percent. ${ }^{1}$

\begin{tabular}{lcccc}
\hline Component & Alumina Calcine & Zirconia Calcine & $\begin{array}{c}\text { Zirconium-Sodium } \\
\text { Blend Calcine }\end{array}$ & High-Sodium Calcine \\
\hline Aluminum & 87.3 & 11.8 & 6.5 & 53.4 \\
Boron & 0.4 & 1.1 & 1.0 & 0.8 \\
Cadmium & & & 5.5 & 0.2 \\
Calcium & & 37.7 & 31.9 & 4.0 \\
Chloride & & & 0.1 & 0.4 \\
Chromium & & 0.4 & 0.1 & 0.1 \\
Fluoride & 30.1 & 21.9 & 1.0 \\
Iron & 0.1 & 0.3 & 0.2 & 0.4 \\
Mercury & 5.5 & & & 0.003 \\
Nitrate & 2.6 & 0.1 & 8.1 & 23.0 \\
Phosphate & 1.1 & & & 0.7 \\
Potassium & 0.1 & 0.1 & 0.9 & 2.5 \\
Sodium & 1.4 & & 4.1 & 11.4 \\
Sulfate & 1.5 & & 3.7 & 1.4 \\
Tin & & 0.3 & 0.2 & 0.3 \\
Zirconium & & 18.2 & 15.5 & \\
\hline A blank cell indicates an insignificant quantity. & & & \\
& & & & \\
\hline
\end{tabular}




\section{Calcined Solids Storage Facility I}

Also known as Bin Set 1 or CPP-729, CSSF I consists of four composite bins (VES-WCS-115-1, 2, -3, and - 4). Each bin in CSSF I contains three sub-bins identified as A-1, A-2, and A-3 as numbered from inside to outside. See Figure A-1 for details. ${ }^{2}$ The facility design was completed by the Fluor Corporation of Los Angeles, California. The bins were fabricated of Type 405 stainless steel in 1959 by Oscar Krenz, of Berkeley. ${ }^{1}$

The innermost A-1 sub-bins, which are not annular, are about $7.6 \mathrm{~m}(25 \mathrm{ft})$ tall and have a $36 \mathrm{in}$. inside diameter, with a bottom made of $5 / 16$ in. plate. The wall thickness varies from $1 / 8$ in. plate at the bottom to $1 / 4$ in. plate at the top. Each annular sub-bin is about $6 \mathrm{~m}(20 \mathrm{ft})$ tall. The inner A-2 sub-bins are made of $1 / 8$ in. plate for the inside walls, $3 / 16$ in. plate for the outside walls, $5 / 16$ in. plate at the bottom, and $1 / 4$ in. plate at the top. The outer A-3 sub-bins are made of 3/16 in. plate for the walls, 5/16 in. plate at the bottom, and $1 / 4$ in. plate at the top. The sub-bins are surrounded by a $1 / 4$ in. carbon steel plate shroud made per ASTM-A7, ${ }^{2}$ Specification for Steel Bridges and Building, ${ }^{3}$ which was replaced in 1967 by ASTM-A36/A36M, Standard Specification for Carbon Structural Steel. ${ }^{4}$ No retrieval access was provided for these bins. The estimated usable capacity of the CSSF is about $227 \mathrm{~m}^{3}\left(8,000 \mathrm{ft}^{3}\right) .{ }^{1}$ No corrosion allowance was identified for the CSSF I bins. ${ }^{5}$ Figure A-2 shows the initial installation of Bin VES-WCS$115-2$.

Numerous internal obstructions are present in each bin, which could hinder calcine retrieval operations. These obstructions include thermowells and internally mounted wall stiffeners and bottom braces.

In April 1979, water entered the CSSF I vault. ${ }^{1}$ The water source was determined to be a ruptured adjacent underground water line. The vault entry mechanism was not determined, and an estimated volume of between 950 and 2,850 L (250 and $750 \mathrm{gal}$ ) of water entered the vault. After the ruptured line was turned off, the water evaporated over time without operational intervention. Whether any water rose to a height where it could contact the bins or interrupt convective cooling air flow is doubtful. ${ }^{1}$ No deterioration of the calcine product or bins has been or is expected. ${ }^{1}$ A remote video inspection of the vault performed in 1995 confirmed the undisturbed condition of the bins. ${ }^{6}$

Between February 1961 and November 1962, CSSF I was used to collect calcine during the nonradioactive testing of the WCF. Before radioactive startup of the WCF, the nonradioactive calcine was removed from the bins. The bins were then filled with nonradioactive alumina startup bed and radioactive alumina calcine ${ }^{7}$ during WCF Campaign 1, which ran from November 1963 to October 1964. During WCF Campaign $1,1.9 \times 10^{6} \mathrm{~L}(512,000 \mathrm{gal})$ of aluminum-fuel reprocessing waste was calcined to produce $217 \mathrm{~m}^{3}\left(7,650 \mathrm{ft}^{3}\right)$ of alumina calcine that filled CSSF I. The highest temperature recorded in CSSF I was $224^{\circ} \mathrm{C}\left(435^{\circ} \mathrm{F}\right)$ in Bin VES-WCS-115-2-A-2 in November $1964 .^{1}$ 
Figure A-1. Sectional Elevation of Calcined Solids Storage Bin Set I Bin. ${ }^{7}$

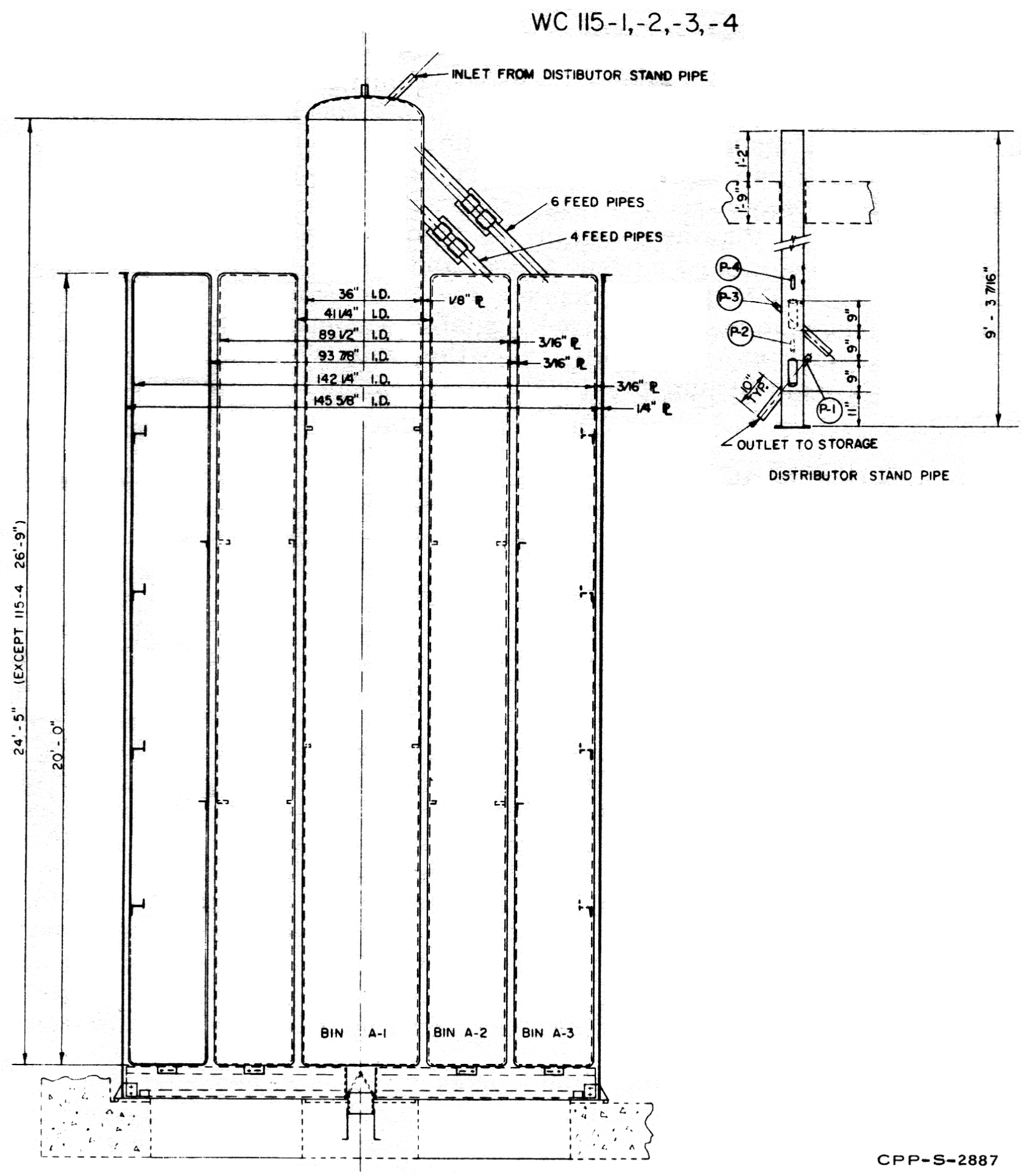




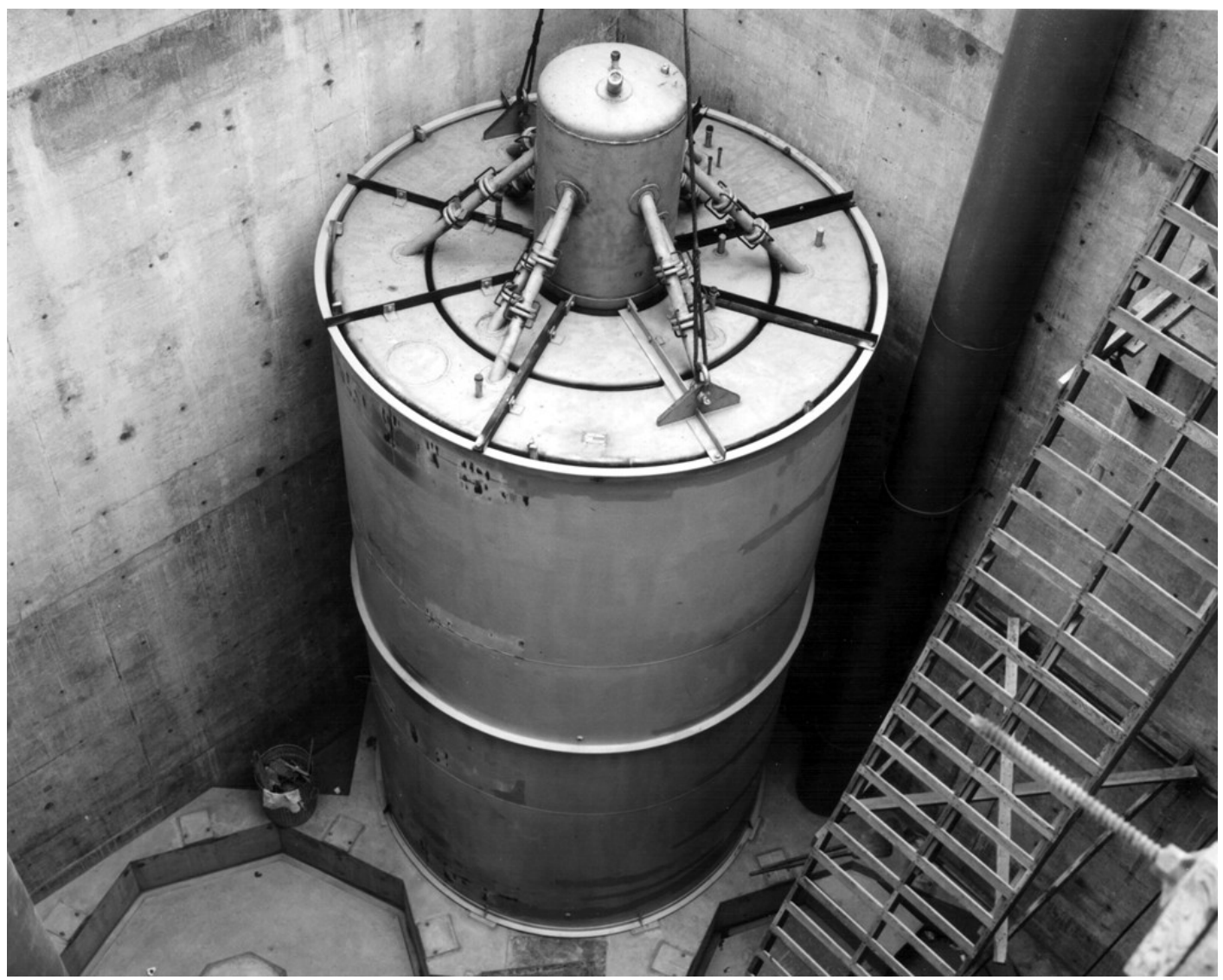

Figure A-2. Calcine storage Bin VES-WCS-115-2 in Calcined Solids Storage Facility I (59-5283).

\section{Calcined Solids Storage Facility II}

Also known as Bin Set 2 or CPP-742, CSSF II consists of seven bins (VES-WCS-136-1, -2, -3, -4, $-5,-6$, and -7). The facility design was performed by Norman Engineering of Los Angeles. Each bin is a standard right circular cylinder and was fabricated of Type 304 stainless steel in 1965 by Chicago Bridge and Iron Works Company, Western Operations, in Salt Lake City. ${ }^{1}$

Each bin is approximately $13 \mathrm{~m}(42.3 \mathrm{ft})$ tall with a $3.7-\mathrm{m}(12-\mathrm{ft})$ outer diameter. ${ }^{8}$ Figure A-3 is a picture of Bin VES-WCS-136-2 prior to installation. The vessel walls are made of $1 / 4$ in. thick plate. Each bin is fitted with a 6-inch Schedule 40S retrieval nozzle. ${ }^{9}$ The usable volume of CSSF II is approximately $856 \mathrm{~m}^{3}\left(30,200 \mathrm{ft}^{3}\right)$. A corrosion allowance of $0.3 \mathrm{~cm}\left(0.125 \mathrm{in}\right.$.) was provided for all bin plates. ${ }^{5}$

The principal internal obstructions are thermowells and corrosion coupons. The thermowells are centerline mounted 1 1/2-in. Schedule 160 pipes with associated support hardware. In addition, all bins have a wall-mounted thermowell that enters the vessel wall approximately $3.6 \mathrm{~m}(11 \mathrm{ft})$ from the top of

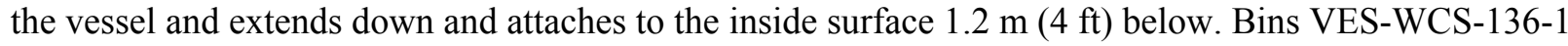
and -4 have an additional wall mounted thermowell approximately $3.6 \mathrm{~m}(11 \mathrm{ft})$ lower. Bins VES-WCS136-1 and -4 also have an array of 12 thermowells, which were installed to monitor the temperature gradient radially from the bin centerline. These thermowells and their support hardware could pose a hindrance to remote operations. Each bin has four, approximately $13 \mathrm{~cm}$ (5 in.) wide, internally attached 
stiffening rings mounted roughly equidistant down the bin wall. Along with the thermowells, three of the original five sets of corrosion coupons remain hung in Bins VES-WCS-136-1 and -4. The coupons are suspended separately from wall-mounted hangers. In 1978, during corrosion coupon removal operations from Bin VES-WCS-136-1, one cable of corrosion coupons was dropped. ${ }^{10}$

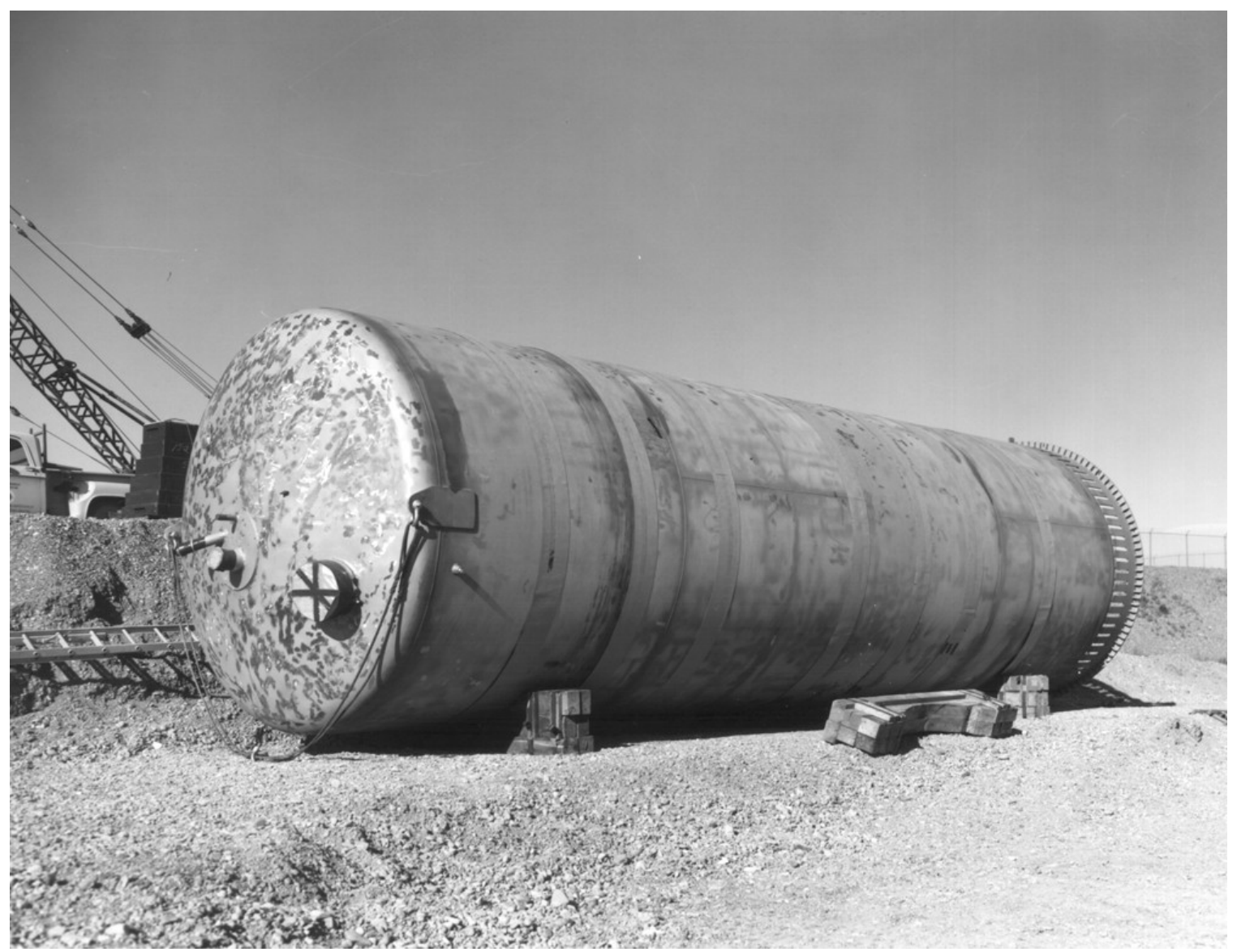

Figure A-3. Calcine storage Bin VES-WCS-136-2 in Calcined Solids Storage Facility II (65-5256).

In April 1966, CSSF II was placed in radioactive service with the startup of WCF Campaign 2. The complete production output of alumina and zirconia calcine from WCF Campaigns 2, 3, and 4 are stored in this CSSF. Filling of CSSF II was completed at about the middle of WCF Campaign 5 in February 1972. ${ }^{11-14}$

The contents of CSSF II consist of about $25.5 \mathrm{~m}^{3}\left(900 \mathrm{ft}^{3}\right)$ of dolomite and nonradioactive alumina, $289 \mathrm{~m}^{3}\left(10,200 \mathrm{ft}^{3}\right)$ of radioactive alumina, and $542 \mathrm{~m}^{3}\left(19,100 \mathrm{ft}^{3}\right)$ of radioactive zirconia calcine. The highest centerline temperature recorded in CSSF II was $696^{\circ} \mathrm{C}\left(1,284^{\circ} \mathrm{F}\right)$ in Bin VES-WCS-136-3 in August 1969. ${ }^{1}$

The design of CSSF II included provisions for calcine product segregation. Collection of calcine to either Bin VES-WCS-136-1 or -2 could be achieved by use of a diverter. Separate storage of zirconia and alumina calcines was planned. However, when the diverter system was activated in the second WCF radioactive waste processing run, Campaign $\mathrm{H}-2$, separation of the two calcines was not achieved because the feed pipe to the diverter became plugged. The plug was cleared after the campaign. ${ }^{1}$ 
The other bins were filled, for the most part, according to the planned order of Bin VES-WCS-136$4,-3,-5,-7$, and -6 from overflow lines located at increasing elevations on the distributor pipe. Calcine distribution from the central distributor pipe was designed so that small amounts of solids accumulated in other bins; therefore, clean breaks between bin contents were not accomplished. This accumulation is the source of some uncertainty in the exact composition of the calcine stored in the lowest areas of the bins. ${ }^{1}$

Sampling of the solids in two bins in CSSF II was performed in 1978. Alumina calcine stored in Bin VES-WCS-136-3 and zirconia calcine from Bin VES-WCS-136-7 were sampled by pneumatic retrieval through inserting a long probe into the full bins. The probe retrieved material at multiple depths throughout each bin. The results of this sampling and analysis effort confirmed that stored calcine could be pneumatically retrieved. ${ }^{15}$

\section{Calcined Solids Storage Facility III}

Also known as Bin Set 3 or CPP-746, CSSF III consists of seven bins (Bin VES-WCS-139, which was later renamed Bin VES-WCS-140-7, VES-WCS-140-1, -2, -3, -4, -5, and -6) similar to those in CSSF II, except that the center bin is taller as shown in Figure A-4. The facility design was completed by Idaho Nuclear Corp, Idaho Falls, Idaho. The bins were fabricated of Type 304 stainless steel in 1969 by

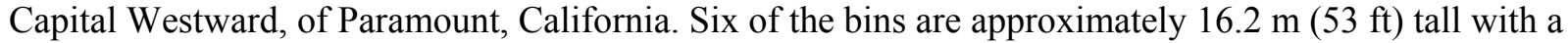
$3.6 \mathrm{~m}$ (12-ft) outer diameter. The seventh bin is $18.6 \mathrm{~m}(61 \mathrm{ft})$ tall. The outer bin walls range in thickness from $1 / 4$ in. plate at the top to $7 / 16$ in. plate at the bottom. The center bin walls range in thickness from $1 / 4$ in. plate at the top, $3 / 8$ in. plate in the middle, to $9 / 16$ in. plate at the bottom. The bottom heads are made of 9/16 in. plate, and the top heads are 7/16 in. plate. Each bin is fitted with a 6-inch Schedule 40S retrieval nozzle. ${ }^{16}$ The usable volume of the CSSF is approximately $1,097 \mathrm{~m}^{3}\left(38,700 \mathrm{ft}^{3}\right)$. A corrosion allowance of $0.3 \mathrm{~cm}\left(0.125 \mathrm{in}\right.$.) was provided for all bin plates. ${ }^{5}$

Internal obstructions are centerline-mounted 2-in. Schedule 80 thermowells with their associated support hardware and five sets of corrosion coupons hung from hangers attached to the wall of Bin VES-WCS-140-1. The strings of corrosion coupons are installed through one of the two retrieval nozzles where they are secured from a $1 / 4$-in. "J" hook welded to the inside of the retrieval riser 10 to $13 \mathrm{~cm}$ (4 to $5 \mathrm{in}$.) from its opening. All but one bin has six approximately $13 \mathrm{~cm}$ (5-in.) wide, internally attached stiffening rings mounted roughly equidistant down the bin wall. Bin VES-WCS-140-7 has seven of the rings mounted down the wall. ${ }^{1}$

Two erosion failures occurred in the inlet line to the cyclone for CSSF III, one in October 1976 and another in December 1977. Extensive cleanup of the cyclone vault was required before the replacement of the failed equipment. ${ }^{1}$ For planning purposes, a prudent approach may be to make a conservative assumption that relatively high contamination levels will be encountered for work in the cyclone vault.

In February 1972, CSSF III was placed in radioactive service in approximately the middle of WCF Campaign 5 and, in March 1981, was filled with the completion of WCF Campaign $9 .{ }^{17}$ The CSSF was filled with alumina, stainless steel, zirconia, and zirconia-sodium blend calcines produced during the fifth, sixth, seventh, eight, and ninth WCF processing campaigns. Approximate volumes of calcine sent to storage are $112 \mathrm{~m}^{3}\left(3,950 \mathrm{ft}^{3}\right)$ of nonradioactive alumina, $67 \mathrm{~m}^{3}\left(2,350 \mathrm{ft}^{3}\right)$ of dolomite and fluorapatite from calciner startup, $64 \mathrm{~m}^{3}\left(2,250 \mathrm{ft}^{3}\right)$ of radioactive alumina, $547 \mathrm{~m}^{3}\left(19,330 \mathrm{ft}^{3}\right)$ of zirconia, $172 \mathrm{~m}^{3}$ $\left(6,070 \mathrm{ft}^{3}\right)$ of zirconia-sodium blend, $110 \mathrm{~m}^{3}\left(3,880 \mathrm{ft}^{3}\right)$ of $3.5: 1$ blend ratio, and $62 \mathrm{~m}^{3}\left(2,190 \mathrm{ft}^{3}\right)$ of $5: 1$ blend ratio, and $1.4 \mathrm{~m}^{3}\left(50 \mathrm{ft}^{3}\right)$ of stainless steel calcine. The highest centerline temperature recorded in the third CSSF was $326^{\circ} \mathrm{C}\left(617^{\circ} \mathrm{F}\right)$ in Bin VES-WCS-140-1 in November $1981 .{ }^{1}$ 


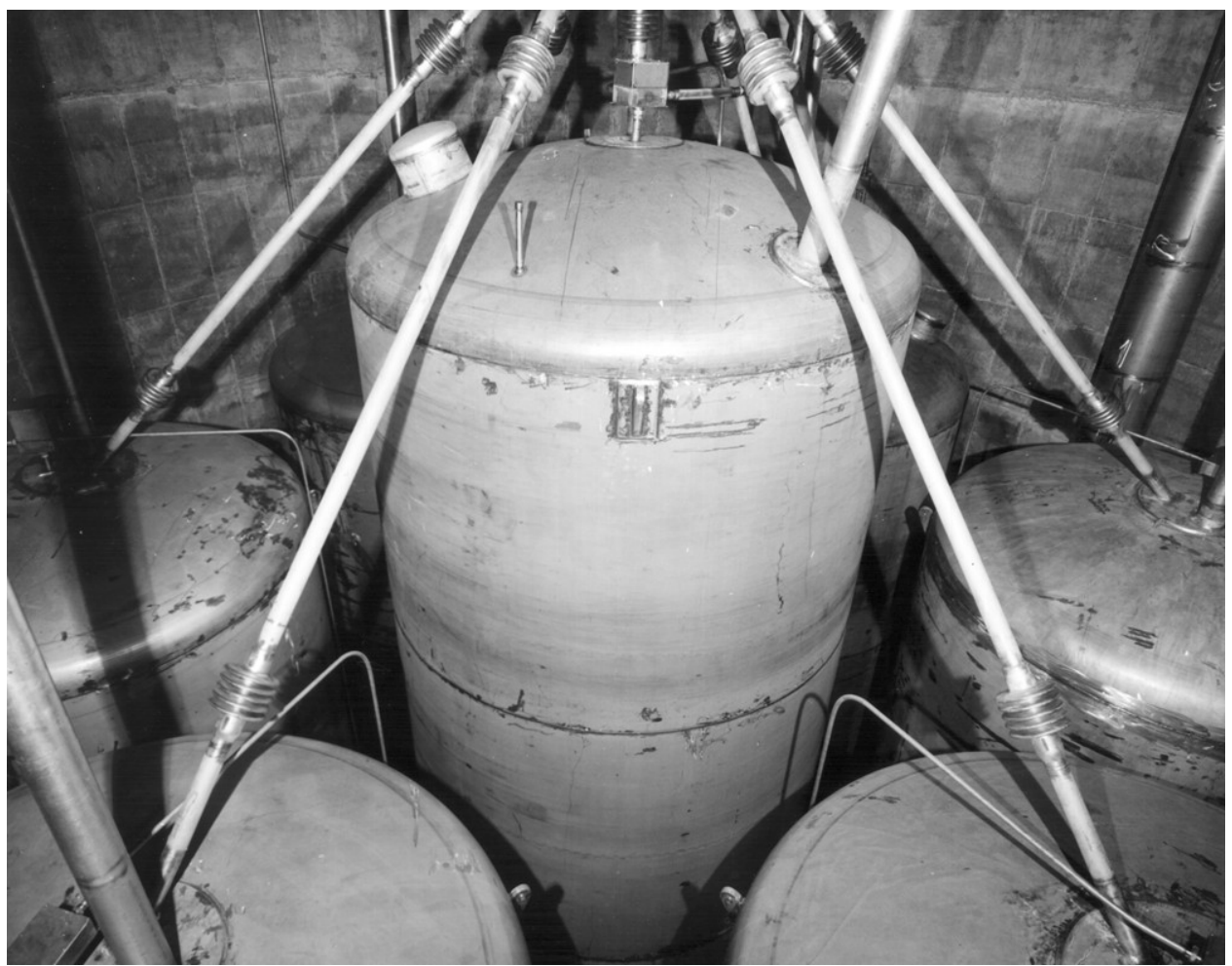

Figure A-4. Center Bin VES-WCS-139 (also known as VES-WCS-140-7) in interior of Calcined Solids Storage Facility III (71-4954).

The design of CSSF III included provisions for calcine segregation. Collection of calcine in Bin VES-WCS-140-1 could be achieved by use of a diverter with the intent that the other bins be filled concurrently. However, data indicate that some preferential filling occurred, which could be attributed to a variety of causes. ${ }^{1}$

\section{Calcined Solids Storage Facility IV}

Also known as Bin Set 4 or CPP-760, CSSF IV consists of three bins (VES-WS4-142, -143, and 144) similar to the CSSF III bins except that the stiffening rings are attached externally. The facility design was completed by Aerojet Nuclear Company of Idaho Falls, Idaho. The bins were fabricated of Type 304 stainless steel in 1976 by Capital Westward of Paramount, California. ${ }^{1}$

Each bin is approximately $17 \mathrm{~m}(55 \mathrm{ft})$ tall with a 3.6- $(12-\mathrm{ft})$ outer diameter. ${ }^{18}$ The bin walls range in thickness from $0.375 \mathrm{in}$. at the top, $0.5 \mathrm{in}$. in the middle, to $0.625 \mathrm{in}$. plate at the bottom. The bottom head has a 0.62 in. minimum thickness, and the top head has a 0.31 in. minimum thickness. ${ }^{19}$ The usable volume of CSSF IV is approximately $488 \mathrm{~m}^{3}\left(17,200 \mathrm{ft}^{3}\right)$. The total general corrosion allowance for the CSSF IV bins is 16 mils (0.016 in.). ${ }^{20}$ Figure A-5 shows Bin VES-WS4-142 during placement.

Internal obstructions are centerline-mounted 2-in. Schedule 80 thermowells with their associated support hardware and five sets of corrosion coupons hung from separate hangers attached to the wall in each of the bins. The strings of corrosion coupon are installed through one of the two retrieval nozzles for each bin. They are secured to $1 / 4-i n$. "J" hooks welded to the inside of the riser 10 to $13 \mathrm{~cm}$ (4 to $5 \mathrm{in}$.) from its opening. ${ }^{1}$ 
In 1979, during the flushing and hydrostatic testing of the product transport line from the NWCF to CSSF IV, water entered the three solids storage bins (none entered the vault). Apparently, the block valves were not fully closed during these operations. In September 1980, approximately 60,500 L (16,000 gal) of water was pumped from the bins. The bins were then air dried to remove any residual moisture. ${ }^{21}$ Between July 1981 and June 1982, CSSF IV was used to collect calcine during nonradioactive testing of the NWCF. Before radioactive startup, the nonradioactive calcine was removed. The bins were filled with radioactive calcine during the first half of NWCF Campaign 1 between August 1982 and July 1983. After May 1983, the diverter in the solids distribution outlet was used to divert solids to Bin VES-WS4-143. ${ }^{22}$ Evidence indicated that the normal filling pipe leading from the distributor to the bin had become restricted. $^{22}$ All bins in CSSF IV were filled by July 1983 and solids storage operations were switched to CSSF V.

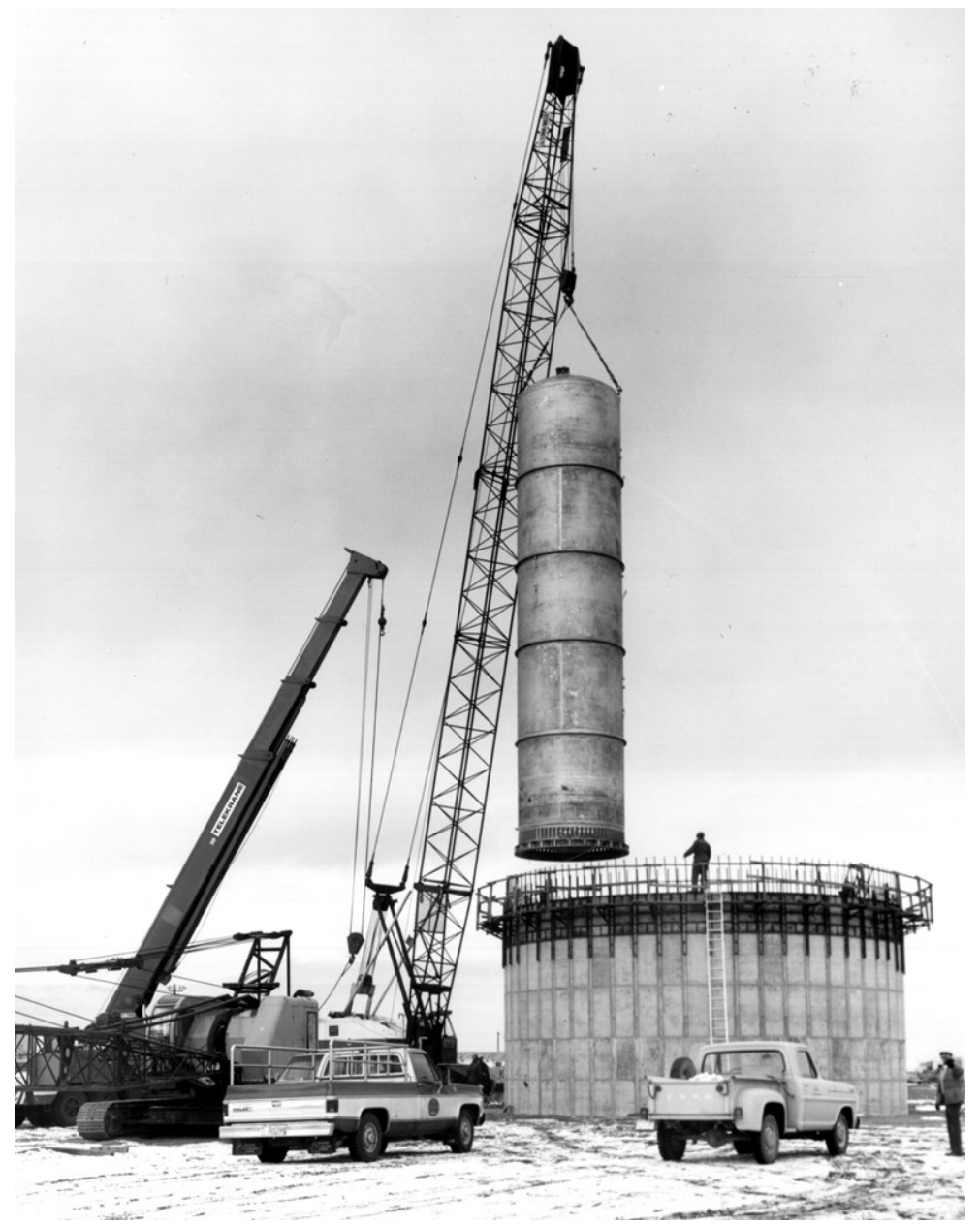

Figure A-5. Installation of Bin VES-WS4-142 in Calcined Solids Storage Facility IV (76-4518).

Between August 1982 and July 1983, CSSF IV was filled primarily with zirconia and zirconia-sodium blend calcines produced during the first NWCF processing campaign. Approximate volumes of calcine sent to storage are $18 \mathrm{~m}^{3}\left(640 \mathrm{ft}^{3}\right)$ of nonradioactive alumina and dolomite from calciner startup, $3 \mathrm{~m}^{3}\left(110 \mathrm{ft}^{3}\right)$ of radioactive alumina-zirconia blend, $146 \mathrm{~m}^{3}\left(5,150 \mathrm{ft}^{3}\right)$ of zirconia, and $321 \mathrm{~m}^{3}\left(11,300 \mathrm{ft}^{3}\right)$ of zirconia-sodium blend calcines. Datasheets indicate that the highest centerline temperature recorded in CSSF IV was $316^{\circ} \mathrm{C}\left(601^{\circ} \mathrm{F}\right)$ in Bin VES-WS4-142 in October 1983. 


\section{Calcined Solids Storage Facility V}

Also known as Bin Set 5 or CPP-765, CSSF V consists of seven bins (VES-WS5-146, -147, -148, $149,-150,-151$, and -152) arranged similarly to CSSF III except that the bins are of annular design. The facility design was completed by EG\&G Idaho of Idaho Falls, Idaho. Capital Westward of Paramount, California fabricated the bins of Type 304L stainless steel in 1978. Each annular bin is approximately 17 $\mathrm{m}(50 \mathrm{ft})$ tall with $3.6-\mathrm{m}(12-\mathrm{ft})$ outer and $3.6-\mathrm{cm}(4-\mathrm{ft})$ inner diameters. ${ }^{23}$ The outer wall thickness varies from $1.6 \mathrm{~cm}(0.625$ in.) at the bottom to $1 \mathrm{~cm}(0.375$ in.) at the top, while the inner wall thickness is $1 \mathrm{~cm}$ ( 0.375 in.) throughout. The top and bottom heads are 0.625 in. minimum thickness. ${ }^{24}$ Each bin is fitted with four 8 -in. schedule 40 retrieval access risers capped with an 8-in. 150-pound weld neck flange. The usable volume of CSSF V is approximately $992 \mathrm{~m}^{3}\left(35,000 \mathrm{ft}^{3}\right)$. Internal obstructions are two 2-in.

Schedule 80 thermowells with their support hardware and five sets of corrosion coupons, which are hung on separate hangers in each of two bins (Bin VES-WS5-149 and Bin VES-WS5-155). The corrosion coupons are accessed through individual 6 -in. Schedule 40 retrieval risers. The corrosion allowance for CSSF V bins is 20 mils (0.020 in.). ${ }^{23}$

Figure A-6 shows the attachment make-up of a typical tank nozzle, fill line, and retrieval connection for one of the bins.

Placed in radioactive service midway through NWCF Campaign 1 in July 1983, CSSF V was filled about mid-way through NWCF Campaign 3 in January 1992. It was filled with alumina, zirconia, zirconia-sodium blend, zirconia-sodium-Rover blend, and sodium-Rover-blend calcines produced during the first, second, and third NWCF processing campaigns. Approximate volumes of calcine are $55 \mathrm{~m}^{3}$ $\left(1,930 \mathrm{ft}^{3}\right)$ of nonradioactive alumina and dolomite from calciner startup, $2 \mathrm{~m}^{3}\left(50 \mathrm{ft}^{3}\right)$ of pilot plant calciner product, and $934 \mathrm{~m}^{3}(32,980) \mathrm{ft}^{3}$ of radioactive calcine from processing of aluminum, zirconium, ROVER, and sodium-blended feedstocks. The highest centerline temperature recorded in CSSF V was $115^{\circ} \mathrm{C}\left(239^{\circ} \mathrm{F}\right)$ in Bin VES-WS5-146 in August $1988 .{ }^{1}$

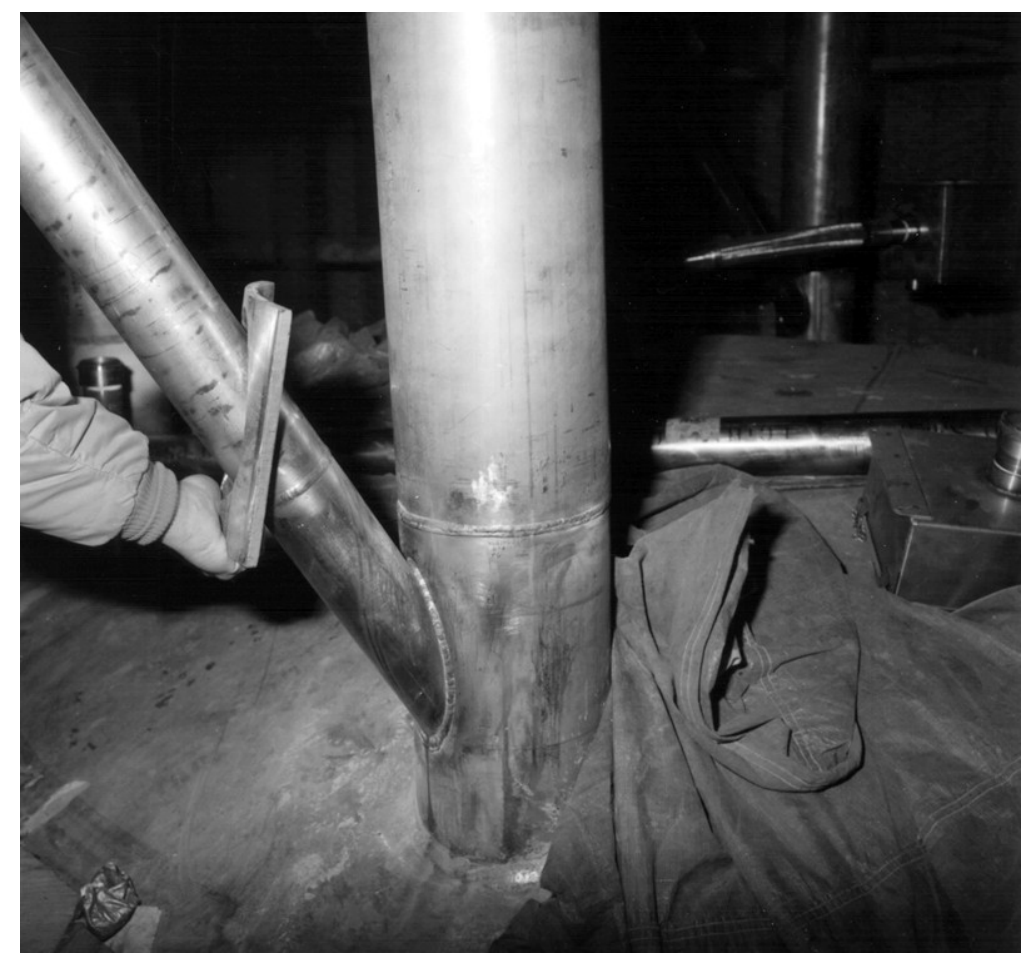

Figure A-6. Typical vessel connections on bin in the Calcined Solids Storage Facility V (81-851). 


\section{Calcined Solids Storage Facility VI}

Also known as Bin Set 6 or CPP-791, CSSF VI consists of seven annular bins (VES-WS6-154, $155,-156,-157,-158,-159$, and -160$)$ similar to CSSF V. The facility design was completed by EG\&G Idaho of Idaho Falls, Idaho. The bins were fabricated of Type 304L stainless steel in 1981 by Mason Steel Fabricating Company of Decatur, Illinois. ${ }^{1}$

Each annular bin is approximately $21 \mathrm{~m}(67.6 \mathrm{ft})$ tall with a $4-\mathrm{m}(13.5-\mathrm{ft})$ outer and a $1.5-\mathrm{m}(5-\mathrm{ft})$ inner diameter. ${ }^{25}$ The outer wall thickness decreases from $1 \mathrm{in}$. plate at the bottom to $3 / 8 \mathrm{in}$. plate at the top, while the inner wall thickness is $9 / 16$ in. plate throughout. Each bin is fitted with four 8 -in. Schedule 40 retrieval access risers, which are attached to 8 -in. Schedule 80 nozzles on the vessels and capped with 8-in. 150-pound weld neck flanges.

Internal obstructions are two 2 -in. Schedule 80 thermowells (located near the annular centerline) with their associated support hardware and five sets of corrosion coupons hung from separate hangers attached to the outer wall in each of two bins (Bin VES-WS6-156 and Bin VES-WS6-159). The usable volume of the CSSF is approximately $1,507 \mathrm{~m}^{3}\left(53,200 \mathrm{ft}^{3}\right)$. The corrosion allowance for the CSSF VI bins is 20 mils ( 0.020 in.). ${ }^{26}$

Figure A-7 is a top view of the distribution piping for CSSF VI. The annular bin design is typical of bins in both CSSF V and CSSF VI.

In January 1993, CSSF VI was placed in radioactive service about midway through NWCF Campaign 3 and is only 49\% filled. Volumes reported include waste processed during NWCF Campaign 4 through June 2000, when the calciner was placed on standby. During the third and fourth NWCF processing campaigns, CSSF VI was partially filled with alumina, zirconia-alumina-sodium blend, and high-sodium calcines. Approximate volumes of calcine are $33 \mathrm{~m}^{3}\left(1,170 \mathrm{ft}^{3}\right)$ of nonradioactive alumina and dolomite from calciner startup and shutdown, and $708 \mathrm{~m}^{3}\left(25,000 \mathrm{ft}^{3}\right)$ of radioactive calcine. Datasheets indicate that the highest centerline temperature recorded in CSSF VI was $67^{\circ} \mathrm{C}\left(153^{\circ} \mathrm{F}\right)$ in Bin VES-WS6-157 in August 1994. 


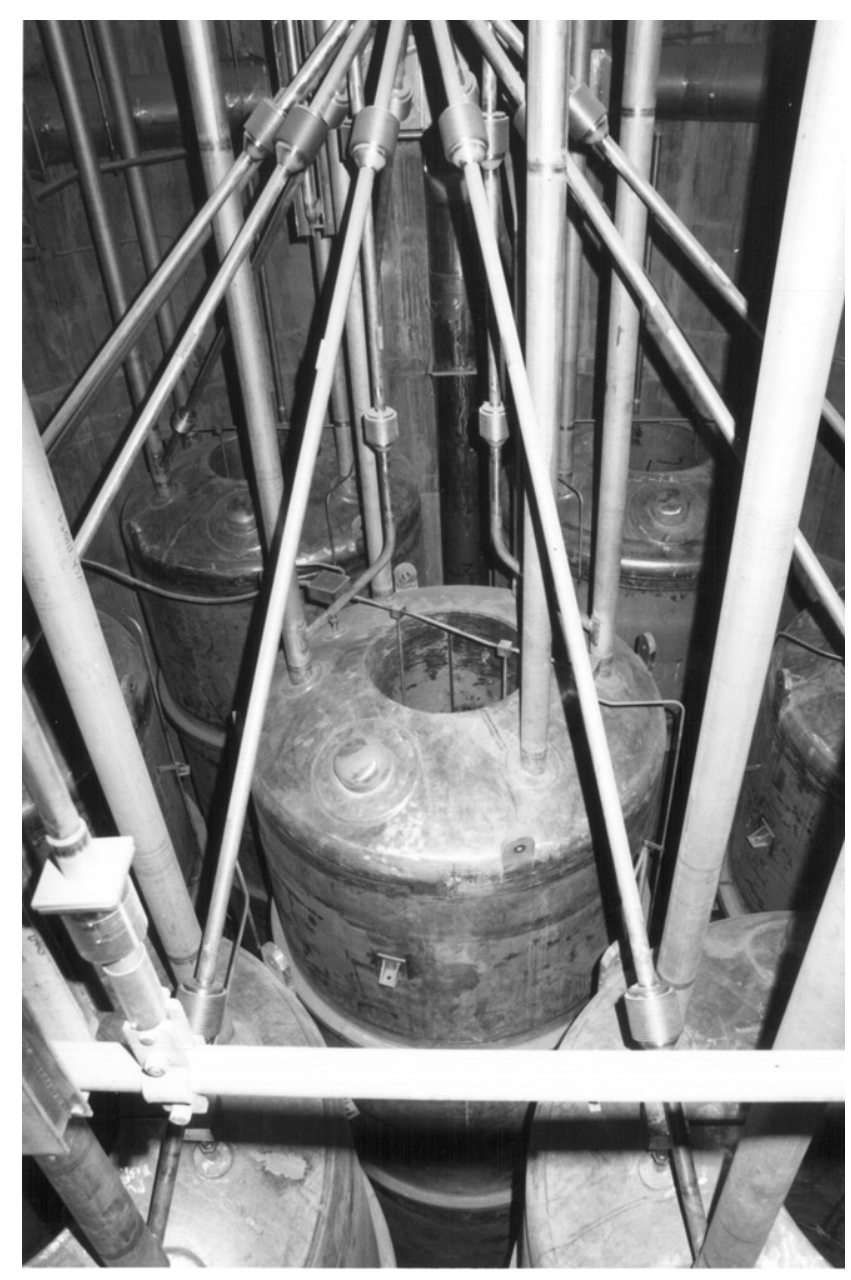

Figure A-7. Distribution piping for Calcine Solids Storage Facility VI (84-680-1-6).

Currently, CSSF VI contains the highest sodium content calcine . In the past, SBW was blended with fuel reprocessing raffinates because of the problems associated with calcining only SBW. In 1998, the last of the fuel reprocessing raffinate was processed from the $\mathrm{TFF}^{27}$; however, more than $1 \times 10^{6} \mathrm{gal}$ of SBW remained. Processing SBW without fuel reprocessing raffinates requires the addition of large volumes of aluminum nitrate nanohydrate to alleviate the bed agglomeration associated with processing straight SBW. However, adding aluminum nitrate nanohydrate greatly increases the amount of calcine that is transported to the CSSFs. To reduce the volume of calcine produced, a method of reducing the amount of aluminum nitrate nanohydrate required to process SBW was developed. The method is referred to as high-temperature calcination and involves increasing the processing temperature of the NWCF calciner to $600^{\circ} \mathrm{C}\left(1,112^{\circ} \mathrm{F}\right)$ from the normal operating temperature of $500^{\circ} \mathrm{C}\left(932^{\circ} \mathrm{F}\right)$. The elevated temperature improves the calcination reaction kinetics, thereby virtually eliminating the operational problems associated with calcining SBW straight at $500^{\circ} \mathrm{C}\left(932^{\circ} \mathrm{F}\right)$ without large volumes of aluminum nitrate nanohydrate. However, the calcine produced, referred to as high-sodium calcine, has been shown to be very hygroscopic and very soluble in water. ${ }^{28}$ Calcine is usually very inert and only slightly soluble in water because of the high concentration of aluminum oxide, zirconium oxide, calcium oxide, and calcium fluoride it contains. By reducing the aluminum nitrate nanohydrate during calcination, highsodium calcine has a reduced concentration of aluminum oxide and an increased concentration of sodium and potassium aluminates, which are hygroscopic and soluble in water. Normally, the heat generated by radioactive decay of the radionuclides in the calcine would be sufficient to drive off any water present in 
the bins; however, the problem is compounded with high-sodium calcine with its low concentration of radionuclides. As noted earlier, the highest centerline temperature in CSSF VI was only $67^{\circ} \mathrm{C}\left(153^{\circ} \mathrm{F}\right)$.

During 1999 and 2000, a large amount of high-sodium calcine was produced and placed in CSSF VI. When the NWCF was shut down, some nonradioactive alumina calcine was produced to clean out the processing system, and was placed on top of the high-sodium calcine.

\section{Calcined Solids Storage Facility VII}

Also known as Bin Set 7 or CPP-795, CSSF VII consists of seven annular bins (VES-WS7-162, $163,-164,-165,-166,-167$, and -168) similar to CSSF VI. The facility design was completed by EG\&G Idaho of Idaho Falls, Idaho. The design of CSSF VII is identical to that of CSSF VI except that the diameter of the annulus is smaller providing additional storage capacity. ${ }^{29}$ The total volume of CSSF VII is $2,124 \mathrm{~m}^{3}\left(75,000 \mathrm{ft}^{3}\right)$ with a usable volume of $1,784 \mathrm{~m}^{3}\left(63,000 \mathrm{ft}^{3}\right)$. By comparison, CSSF VI has a total volume of $1,557 \mathrm{~m}^{3}\left(55,000 \mathrm{ft}^{3}\right)$ with a usable volume of $1,506 \mathrm{~m}^{3}\left(53,200 \mathrm{ft}^{3}\right)$. The bins were fabricated of Type 304L stainless steel in 1985. Currently, CSSF VII is empty. 


\section{APPENDIX A}

\section{REFERENCES}

1. Staiger, M. D., Calcine Waste Storage at the Idaho Nuclear Technology and Engineering Center, INEEL/EXT-98-00455, Idaho National Engineering and Environmental Laboratory, Lockheed Martin Idaho Technologies Company, Idaho Falls, Idaho, June 1999.

2. Drawing 106577, 5775-CPP-729-P-2, CPP-729 Vessel Bin Set I VES-WC-115-1, 2, 3 \& 4 Solids Storage Bins Waste Calcination Facilities, The Fluor Corporation, Ltd., for U. S. Atomic Energy Commission Idaho Operations Office, 1958.

3. ASTM A7, Specification for Steel for Bridges and Building.

4. ASTM A36/A36M, Standard Specification for Carbon Structural Steel.

5. Lohse, G. E., Safety Analysis Report for the ICPP High-Level Solid Radioactive Waste Storage Facilities, ICP-1005, January 1972.

6. Griffith, D. L., CSSF I Storage Vault Inspection Report, INEEL/EXT-97-01376, Lockheed Martin Idaho Technologies Company for U. S. Department of Energy, June 1998.

7. Commander, R. E., et al., Operation of the Waste Calcining Facility with Highly Radioactive Aqueous Waste, Report of the First Processing Campaign, IDO-14662, U. S. Atomic Energy Commission Idaho Operations Office, June 1966.

8. Bendixson, C. L. and G. E. Lohse, Storage Facilities for Radioactive Calcined Waste Solids at the Idaho Chemical Processing Plant, IN-1155, Idaho Nuclear Corporation for U. S. Atomic Energy Commission Idaho Operations Office, July 1968.

9. Drawing 118871, 1200-CPP-742-P-10, Additional Calcined Waste Storage Facilities Solids Storage Bins, Norman Engineering Company for U. S. Atomic Energy Commission Idaho Operations Office, 1965.

10. Schofield, J. S., Dropping of Corrosion Coupons into Bin Set \#2, JSS-11-78, May 26, 1978.

11. Lohse, G. E. and M. P. Hales, Second Processing Campaign in the Waste Calcining Facility, IN-1344, Idaho Nuclear Corporation for U. S. Atomic Energy Commission Idaho Operations Office, March 1970.

12. Bendixson, C. L., G. E. Lohse, and M. P. Hales, The Third Processing Campaign in the Waste Calcining Facility, IN-1474, Idaho Nuclear Corporation for U. S. Atomic Energy Commission Idaho Operations Office, May 1971.

13. Weilang, J. A., G. E. Lohse, and M. P. Hales, The Fourth Processing Campaign in the Waste Calcining Facility, FY-1971, ICP-1004, March 1972.

14. Weilang, J. A. and W. A. Freeby, The Fifth Processing Campaign in the Waste Calcining Facility, FY-1972, ICP-1021, June 1973. 
15. Staples, B. A., G. S. Pomiak, and E. L. Wade, Properties of Radioactive Calcine Retrieved from the Second Calcined Solids Storage Facility at ICPP, ICP-1189, March 1979.

16. Drawing 153510, 1230-CPP-746-P-3, Phase III Calcined Solids Storage Facility Addition Storage Bins, Idaho Nuclear Corporation, for U. S. Atomic Energy Commission Idaho Operations Office, 1970.

17. Childs, K. F., R. I. Donovan, and M. C. Swenson, The Ninth Processing Campaign in the Waste Calcining Facility, ENICO-1100, April 1982.

18. Schindler, R. E., Revised Design Criteria for ICPP Fourth Calcine Solids Storage Facility, ACI-165, October 1975.

19. Drawing, Calcined Solids Storage Facility Fourth Addition Storage Bins, Capital Westward, Inc.

20. Schindler, R. E., Final Safety Analysis Report for the Fourth Calcined Solids Storage Facility, ENICO-1031, February 1980.

21. Unusual Occurrence Report 80-20, "Water in the $4^{\text {th }}$ bin set," Exxon Nuclear Idaho Company, Inc., closed October 2, 1980.

22. Penwell, D. L., Calcined Waste Inventory for Calcined Storage Facility IV, WINCO-1162, October 1993.

23. Cummings, K. N. and R. E. Schindler, Project Design Criteria for the ICPP Fifth Calciner Solids Storage Facility, ACI-220, August 1977.

24. Drawing Aperture Card 126134, $5^{\text {th }}$ Addition Calcine Solids Storage Bins, Capital Westward, Inc. 1978.

25. Mozes, R. F., Project Design Criteria for the ICPP Sixth Calcined Solids Storage Facility, ENI-101, November 1979.

26. EG\&G Idaho, Inc., Users Design Specifications for ICPP Sixth Calcined Solids Storage Facility Storage Bins, Subcontract No. 3289, November 1980.

27. Hovinga, J. E., Lockheed Martin Idaho Technologies Company, to J. L. Lyle, U.S. Department of Energy, Idaho Operations Office, "Completion of HLW Calcination," JEH-06-98, February 23, 1998.

28. Nenni, J. A. and D. R. Marshall, Flowsheet Development for Calcination of WM-185 Waste During NWCF Operation in March Through June 1999, INEEL/EXT-01-00832, June 2001.

29. Drawing $165772,7^{\text {th }}$ Set Calcined Solids Storage Facility Bins, EG\&G Idaho, Inc., for U. S. Department of Energy Idaho Operations Office, 1985. 


\section{Appendix B}

\section{Degradation Mechanisms}


B-2 


\section{Appendix B}

\section{Degradation Mechanisms}

The discussion in the following sections is focused on degradation mechanisms caused by dissolved calcine; however, because the possibility of water entering the bins is very unlikely, these degradation mechanisms are all considered insignificant.

General Corrosion. General, or uniform, corrosion is the constant and continuous loss of material from a surface of the material in contact with a corrosive fluid. For austenitic stainless steel in contact with dissolved calcine, the rate of general corrosion is very low.

Pitting and Crevice Corrosion. Pitting corrosion is a common type of localized corrosion in stainless steels. Basically, an electrochemical cell is formed, consisting of a small anodic (corroding) area surrounded by a larger cathodic (noncorroding) surface region that stimulates the localized dissolution at the anode. Once started, pits may continue to grow autocatalytically. Crevice corrosion is associated with geometries where a localized area is occluded, setting up anode-cathode relationships closely related to conditions for pitting corrosion. ${ }^{1}$

The Brookhaven guidelines ${ }^{1}$ state that although austenitic stainless steels may have very low general corrosion rates, they often pit severely, particularly in the presence of chlorides. The chloride ion, and other halogen ions, can cause local breakdown of passivity on the surface of stainless steels in contact with solutions. As pitting proceeds, the concentration of oxygen inside the pit decreases while the concentration of chloride and acid increases. These actions cause an increase in the rate of attack. Local corrosion starting in an occluded region acts in the same way as pitting with the resulting crevice propagating by the same mechanism.

Ions exist only in a liquid medium. Because of the solid condition of calcine, neither pitting nor crevice corrosion is considered to be a significant aging mechanism in the CSSFs. If the calcine were to become wet, it could contain high concentrations of chlorides and other halogen ions, and pitting could become a degradation mechanism. However, the presence of hydroxide ions in solution has been found to mitigate the onset of pitting. ${ }^{1}$

Stress-Corrosion Cracking. Stress-corrosion cracking occurs where a normally ductile metal, like stainless steel, fails in a brittle manner by cracking. The cracks can extend through the wall thickness of a vessel and cause leakage. The necessary conditions for this to occur are a susceptible material, tensile stress, minimum threshold temperature, and a particular corrosive environment. These conditions can be met for stainless steels where the corrosive environment contains a chloride ion. Welding causes residual tensile stress, which is sustained unless a stress-relieving treatment is performed on the material. Welding also causes changes to the material adjacent to the weld, making it also susceptible to some forms of stress-corrosion cracking.

Because of the solid condition of calcine, stress-corrosion cracking is not considered to be a significant aging mechanism in the CSSFs. Calcine could contain chlorides, but not as ions in solution unless the calcine were to become wet.

Microbiologically Induced Corrosion. Microbiologically induced corrosion is corrosion of a material from microbial action. It is more liable to occur in buried tanks or piping, or in tanks in the presence of stagnant water. Both microbiologically induced corrosion and the subsequent localized concentration cell corrosion are unpredictable until they occur. 
Microbiologically induced corrosion is unlikely to occur in CSSF bins unless a large in-leakage of water into the CSSF vaults also occurred. Experience with CSSF I indicates that water in the vault would evaporate and not remain stagnant. ${ }^{2}$ Therefore, this is not a significant degradation mechanism for the bins.

Concentration Cell and Waterline Corrosion. Concentration cell corrosion is localized attack on steel where concentration gradients are in contact with the material. Waterline corrosion, a specific type of concentration cell corrosion, results from local differences in $\mathrm{pH}$ at the surface of the waste.

Neither of these corrosion mechanisms is likely to occur in the CSSF bins. Variations in calcine composition would not be expected to cause concentration gradients because of the calcine being in a solid form and lack of moisture.

Other Aging Mechanisms. Several aging mechanisms discussed in the Brookhaven Guidelines ${ }^{1}$ are classified as insignificant for HLW storage vessels in general. Specifically, for the CSSF bins, these mechanisms are also insignificant. The insignificant aging mechanisms include thermal embrittlement, radiation embrittlement, creep and stress relaxation, fatigue, erosion and erosion-corrosion, wear, and hydrogen embrittlement.

Erosion of transfer piping during filling of the bin sets caused failure of some lines, but this degradation mechanism is no longer present because the areas where the failures occurred are no longer exposed to the calcine erosion. In addition, temperature and radiation levels are not high enough to cause embrittlement or creep.

\section{Vault Degradation Mechanisms}

The degradation mechanisms that may affect the concrete and structural steel that make up the CSSF vaults are described in the following sections. These mechanisms have the potential of preventing the vaults from performing their intended functions.

Elevated Temperature. When conventional concrete is exposed to temperatures in the range of 66 to $95^{\circ} \mathrm{C}\left(151\right.$ to $\left.203^{\circ} \mathrm{F}\right)$, it begins to experience reactions involving the loss of absorbed and combined water from the cement paste and possible thermal incompatibilities between the cement paste and the aggregate. The result of this exposure is reduced compressive strength and stiffness of the concrete. ${ }^{1}$

The calcine that is stored in the bins exceeded the threshold temperatures for thermal degradation of concrete. However, under normal conditions, the concrete vaults were not exposed to these temperatures because of the air space between the bins and the vaults, where natural convection occurs to remove heat. Design features of the CSSFs prevent the exposure of the concrete to excessive heat.

Temperatures in the CSSFs are monitored and, with one exception, the concrete temperatures have always been maintained well below applicable design limits and those values at which thermal degradation would occur. However, as part of a test, air flows through CSSF I were stopped for 5-1/2 months beginning in September 1964 , allowing the vault temperature to rise well above $100^{\circ} \mathrm{C}\left(212^{\circ} \mathrm{F}\right)$. Interior concrete temperatures were not measured, but temperatures of 45 to $50^{\circ} \mathrm{C}\left(113\right.$ to $\left.122^{\circ} \mathrm{F}\right)$ were measured at the concrete/soil interface outside the vault. Airflows were reestablished to avoid needless high temperature degradation of the concrete. Visual inspection of the vault in 1995 identified no visible evidence of structural defects, damage, or degradation to the storage vault walls. ${ }^{3}$

Aggressive Chemical Attack. Some chemicals in solutions may cause degradation of concrete when the concrete is exposed to such solutions. Strong acids cause degradation because of the high alkalinity of concrete (a pH greater than 12.5). Sulfates, contained in some soils and groundwater, also are 
potential sources of chemical attack. These chemical attacks increase the porosity and permeability of the concrete, reduce the alkalinity of the concrete, and subject the concrete to further deterioration that can result in reduced compressive strength and stiffness. ${ }^{1}$ In the unlikely event that a path were created for water to enter the bins and the dissolved calcine caused the bins to rupture, the released alkaline liquid would not likely cause degradation of the vault. Therefore, this mechanism is insignificant for CSSF vaults. Chemical attack from the outside of the vaults from soils and ground water also is insignificant because the underground outside walls of all but CSSF I are protected with a coating of pitch. Chemical attack on the thick concrete wall of CSSF I by chemicals in soil or groundwater would not affect the vault structural integrity. Visual inspection of the CSSF I vault in 1995 identified no visible evidence of structural defects, damage, or degradation to the storage vault walls. ${ }^{3}$

Corrosion of Reinforcing Steel. This aging mechanism is similar to aggressive chemical attack except that the chemical attack is on the reinforcing steel rather than the concrete. For the same reasons as discussed previously, corrosion of reinforcing steel is not a potentially significant source of vault degradation.

Other Aging Mechanisms for Vaults. Several aging mechanisms discussed in the Brookhaven guidelines ${ }^{1}$ are classified as insignificant for HLW storage tank vaults in general. Specifically, for the CSSF vaults, these mechanisms also are insignificant. The insignificant aging mechanisms include freezing and thawing, leaching of calcium hydroxide or other soluble constituents, microbiologically induced corrosion reaction of aggregates with alkalis, creep and shrinkage, abrasion and cavitation, and irradiation. Damage caused by freezing and thawing of the freestanding CSSF vaults would be visible and could be corrected if necessary. The buried vaults are covered with pitch to prevent exposure to groundwater, and are for the most part below the freeze level, thus minimizing the potential for damage from freezing and thawing. 


\section{APPENDIX B}

\section{REFERENCES}

1. Bandyopadhyay, K., S. Bush, M. Kassir, B. Mather, P. Shewmon, M. Streicher, B.

Thompson, D. van Rooyen, and J. Weeks, Guidelines for Development of Structural Integrity Programs for DOE High-Level Waste Storage Tanks, BNL-52527, Brookhaven National Laboratory, Upton, New York, January 1997.

2. $\quad$ Staiger, M. D., Calcine Waste Storage at the Idaho Nuclear Technology and Engineering Center, INEEL/EXT-98-00455, Idaho National Engineering and Environmental Laboratory, Lockheed Martin Idaho Technologies Company, Idaho Falls, Idaho, June 1999.

3. Griffith, D. L., CSSF I Storage Vault Inspection Report, INEEL/EXT-97-01376, Lockheed Martin Idaho Technologies Company for U. S. Department of Energy, June 1998. 